\title{
TOWARDS THE DECARBONISATION OF ECUADOR. A MULTI-SECTORAL AND MULTI- REGIONAL ANALYSIS OF ITS CARBON FOOTPRINT.
}

\author{
Rocío Román-Collado ${ }^{a, b}$; María Teresa Sanz-Díaz ${ }^{a}$ Cristian Germán Loja Pacheco ${ }^{a}$ \\ a Universidad de Sevilla (Spain) ${ }^{1}$ \\ b Universidad Autónoma de Chile (Chile)
}

\begin{abstract}
:
Globally, interest in the environment and its conservation is growing and primordial. In particular, $\mathrm{CO}_{2}$ emissions generated by productive processes in a given territory in order to satisfy own and global consumption. Two types of responsibilities stand out, the producer's and the consumer's. Based on the Multi-regional Input-Output Methodology, this study determined Ecuador's responsibility in terms of $\mathrm{CO}_{2}$ emissions, defining the economic sectors that have the greatest representation in these emissions, as well as establishing an assessment at the level of the Trade Balance. There has been a strong growth of Ecuador's Footprint of 145.26\% from 2000 to 2015, with the transport and secondary sectors having the highest representation and the trade with the BRICS nations standing out. This results strengthens the need to foster a change in the population's and the public administrations' consumption patterns. So it is recommended that the authorities allocate part of the public budget to measures oriented to sustainable consumption.
\end{abstract}

KEYWORDS:

Multi-regional Input-Output Analysis, $\mathrm{CO}_{2}$ Emissions, Carbon Footprint, Emissions Trade Balance, Ecuador, EORA

\footnotetext{
${ }^{1}$ Universidad de Sevilla. Facultad de Ciencias Económicas y Empresariales. Avda. Ramón y Cajal, 1. Sevilla. España.
} 


\section{TOWARDS THE DECARBONISATION OF ECUADOR. A MULTI-SECTORAL AND MULTI- REGIONAL ANALYSIS OF ITS CARBON FOOTPRINT.}

\section{Introduction}

Climate change has especially increased the vulnerability of Latin American countries in which, according to what the Corporación Andina de Fomento (Andean Development Corporation) (2014) considers, more than half of the region's population lives in a high or extreme risk of susceptibility to climate change. According to the projection of the Red Iberoamericana de Oficinas del Cambio Climático (Ibero-American Network of Climate Change Offices) (RIOCC 2020) this vulnerability is on the rise. There are various motives and sensitive focal points: the increase of the temperature and its impact on the reduction of the glaciers of the Andes and on the semi-arid zones of countries such as Chile or Brazil; the rise of the sea level and its effect on coastal countries, especially in large cities such as Buenos Aires or Rio de Janeiro; and the major frequency and intensity of cyclones, among others (Margulis 2016; RIOCC 2020).

The case of Ecuador stands out for its great natural heritage and a broad diversity of ecosystems, which are threatened by the consequences of meteorological disasters stemming from climate change (República de Ecuador 2017). Since the Constitution of 2008, Ecuador has launched numerous policy instruments referring to the mitigation of climate change and the preservation of the environment (República de Ecuador 2008). The first steps were taken by the Plan Nacional del Buen Vivir (National Plan for Wellbeing) (SENPLADES 2009 and 2013), after which a wide range of policies were articulated to attain climate-related aims. Nonetheless, during these first years most of these policies were part of abstract plans, independently approved by the different ministries and without there being sufficient coordination. This highlighted a lack of effectiveness and the inexistence of specific measures (Buenaño 2017; Jakob 2017).

In 2015 Ecuador presented the UN Framework Convention on Climate Change (UNFCCC) with the Contribución Tentativa Nacionalmente Determinada (Intended Nationally Determined Contribution) (INDC) of Ecuador. It is here seen that the country's central 
axis for the fight against climate change is decarbonisation, the change of the energy matrix and actions in the forestry sector. In 2016, the signing of the Paris Agreement in New York meant a great boost for the elaboration of a more specific legislative framework, such as is the case of the Código Orgánico Ambiental (The Environment Organic Code) (República de Ecuador 2017). This legislation has updated and supplemented that in force in Ecuador oriented at the management of climate change. Title VI of this Code is about sustainable consumption, proposing in various of its articles the fostering of consumption which is sustainable with the environment, the reduction of the ecological footprint, the promotion of information for the consumer to access environmentally sustainable goods, and even the implementation of procedures to prioritise the purchase of sustainable goods in the public area.

Later, in 2018, Ecuador adopted, via the Executive Decree $N^{\circ} 371$, the Agenda 2030 for Sustainable Development. Work had however begun in this direction with the approval of the National Development Plan 2017-2021 “Toda Una Vida" ("An Entire Lifetime") (Secretaría Nacional de Planificación y Desarrollo 2018). This national plan is framed in the 17 Aims of Sustainable Development. Aim 12 is oriented to sustainable production and consumption. To this effect, the country must address not only the national production and consumption but take into account the sustainability of its imports. In this area, it is important to highlight that Ecuador has experienced a significant 13.6 points decrease of its external openness rate in the period 2000-2018, due largely to the reduction of the percentage of exports of the GDP and caused by a much higher growth of imports (172.5\%) than that of exports (76\%).

In 2019, the Decree no 840 published the First Contribution determined at a national level (NDC) for the Paris Agreement under the United Nations Framework Convention on Climate Change (República de Ecuador 2017). The general aim which is established in this planning is to implement policies, actions and efforts which foster the reduction of greenhouse gases and the increase of resilience, and the decrease of vulnerability to the adverse effects of climate change in prioritised sectors. This NDC likewise establishes the aims of reduction of emissions in line with the Paris Agreement, reductions of emissions of between 9 and 20\% for the sectors of Energy, Agriculture, Industry and Waste, and between 4 and $20 \%$, for the land sector and the uses of the land. 
As is reflected in the NDC, though Ecuador is responsible for a minimum percentage of GHG emissions globally, it is committed to the global fight against climate change. Specifically, $0.12 \%$ of the global emissions of 2014 correspond to Ecuador (Banco Mundial 2020), so the interest in their reduction and analysis does not derive from the weight of these emissions in the total count, but its potential growth. Between 2000 and 2014, the increase of Ecuador's total $\mathrm{CO}_{2}$ emissions was the greatest of the countries of South America -111.98\%- while for the rest of the Latin America and the Caribbean (LAC) region the increase was $40.92 \%$, more consistent with the increase of emissions at a world level (46.37\%). If we consider the $\mathrm{CO}_{2}$ emissions per capita during this same period, in the case of Ecuador this growth was $68.52 \%$, a percentage only surpassed by Peru among Latin American countries (79.21\%) and much higher than the region's average, as for LAC the emissions per capita grew $19.06 \%$ and at a world level $23.36 \%$.

Previous works confirm this evolution in Ecuador's $\mathrm{CO}_{2}$ emissions during a broader period. Specifically, Román-Collado and Morales (2018) show that despite Ecuador being a country with a low GDPppp growth, it had a high $\mathrm{CO}_{2}$ emission growth between 1990 and 2013. In fact, the increase of $\mathrm{CO}_{2}$ emissions is a concern shared by many emerging economies, as previous studies have shown (Muñoz \& Steininger 2010). However, this significant growth of $\mathrm{CO}_{2}$ emissions is a key element that can condition Ecuador's commitments reflected in the NDC.

The aim of this study is to analyse the changes that have taken place in Ecuador in the emissions generated from the production and consumption perspective in the 20002015 period based on a Multi-regional Input-Output model (MRIO). This analysis will enable identifying the key production sectors as well as the countries relevant for the generation of Ecuador's Carbon Footprint (CF). The results obtained provide support for decision making in the national planning of environmental policies.

MRIO-based studies allow analysing emissions linked to a country or a region's internal trade from both the consumer's and the producer's perspective. In particular, one of the applications of these models is the calculation of the CF, permitting the calculation of emissions according to the consumption approach (Muñoz \& Steininger 2010; Bonilla et al 2015). This type of analysis quantifies direct and indirect emissions (embodied) by product to satisfy a specific final demand. That is to say, the consumption-based 
approach assigns the responsibility of the emissions to the country or region which acquires specific goods and services which embody emissions (Dolter \& Victor 2016).

This means to respond to key research questions, such as: what have been the key explanatory sectors of Ecuador's $\mathrm{CO}_{2}$ emissions growth in the most recent period, and is Ecuador's production and consumption model sustainable in light of the increase of imports? In the first case, it aims to analyse the evolution of the emissions of the main sectors. These would have a greater margin to centre the measures directed at a longterm strategy and the fulfilling of the objectives foreseen. In the second case, its importance derives from the need to find out the evolution of the consumer's behaviour from the CF point of view to identify if that increase of imports is associated with sustainable consumption and, therefore, clean products or, on the contrary, is based on goods with a greater environmental load.

As far as we are aware, this is the first time a sectoral analysis of the emissions embodied in national production (including exports) but also, the emissions embodied in imports from Ecuador during the period 2000-2015 has been carried out. This analysis allows us to identify the most polluting national sectors and worldwide regions that are involved in Ecuador's national and international trade.

This work is organised as follows. After this introduction, Section 2 presents a review of the scientific literature on the study's topic. Section 3 develops the methodology based on an MRIO approach and describes the data. Section 4 sets out the main results of the model and in Section 5 the results are discussed. Finally, the conclusions and policy recommendations appear in Section 6.

\section{Literature review.}

The fight against climatic change is a priority for Ecuador, especially due to its being vulnerable to the dramatic effects that this causes, owing to both its equatorial geographical situation and its economic situation (Toulkeridis et al. 2020). Yet, as Jakob (2017) points out, there is a paucity of scientific studies which analyse decarbonisation strategies and the evolution of GHG emissions for lower per capita income countries. This is therefore a matter which it is necessary to go more deeply into (Toulkeridis et al. 
2020). The literature has some studies which mainly analyse the evolution of $\mathrm{CO}_{2}$ emissions, their relation with the GDP trend and the policies of decarbonisation.

Some of these works are centred on the region of Latin America and contribute data for Ecuador, as is the case of the analysis of Robalino-López et al. (2016) and Román-Collado and Morales (2018). Ecuador was classified by Román-Collado and Morales (2018) as a country with a low GDPppp growth and high $\mathrm{CO}_{2}$ emission growth between 1990 and 2013. Concretely, the $\mathrm{CO} 2$ emission growth was due to an important increase in population, but there was also a notably increase in fossil fuels use. In fact, Ecuador is identified as a high carbon intensity country compared with the Latin American average (Robalino-López et al. 2016).

Robalino-López et al. (2014a, 2014b) analyse Ecuador's situation regarding the evolution of its economic growth and emissions, showing the importance of promoting renewable energies and the need for a change of the production model to decouple both variables. Specifically, some research is focused on the analysis of the sustainable electrification of Ecuador in different production sectors. In particular, Carvajal and Li (2019) and Carvajal et al. (2019) show the environmental impact of hydroelectric plants and their possible alternatives; Ramírez et al. (2019) and Martínez et al. (2017) analyse the change in the use of GLP to cook by electricity; and Ramírez et al. (2018) focus on public transport electrification.

On the other hand, the work of Jakob (2017) carries out an analysis of Ecuador's energy policies from the point of view of mitigation. More specifically, there are also works focused on the analysis of specific energy policy measures oriented at the reduction of emissions, such as that of Jacobs et al. (2013) concerning the feed-in tariff instrument, and the study of the fuel subsidies system which Escribano describes (2019), and Martínez et al. (2017) and Schaffitzel et al. (2020) analyse.

There exist some studies for Ecuador about the human footprint, such as those of David et al. (2015) and Tapia-Armijos et al. (2017), which highlight the duality faced by those countries which have a broad ecological diversity but also a strong pressure to increase their economic development levels. This pressure is transmitted concerning their vast 
natural resources (Escribano 2013). As far as we know no studies about Ecuador's CF have been published.

Nonetheless, Ecuador's international trade relations have been the subject of study, though not directly related with the volume of emissions. As Lapeña and Czubala (2018) show, Ecuador's main trade partners are the USA and China. In recent years, a rapprochement with the latter has taken place, as well as an increase in the presence of Chinese products in Ecuadorian imports, both Chines investments in major Ecuadorian projects and the granting of aids and loans by Chinese financial entities have risen. Yet, as Samanamud (2014) reflects, this relation is very asymmetric due to China being a fundamental pillar of Ecuador's external trade, while Ecuador is just one more partner that the Asian giant uses to increase its production capacity, making use of the former's natural resources.

Various works analyse international relations and, very especially, the role of China's investments and financial aids, such as those by Escribano (2013), Hogenboom (2014), Casanova et al. (2016), Blanchard (2019) and Lapeña and Czubala (2018). They reflect how these financial aids by the Asian country are not always welcomed by broad sectors of the recipient countries' populations. Herrera-Vinelli (2017) remarks the strong financial dependence that Ecuador has with the Popular Republic of China, its debt in relation with its economy having become large. Notwithstanding, Ecuador considers international aid necessary to advance its development. Specifically, the aims of reducing emissions proposed by Ecuador in the NDC (a 20\% reduction) are conditioned by international aid and support (Torres, 2019).

\section{Methodology and Database}

\subsection{Methodology}

IO analysis based on the development of Leontief $(1936,1970)$ is founded on the analysis of Input-Output tables which describe the inter-relations between an economy's distinct sectors. They detail the monetary flows of goods and services between different sectors as well as the final demand (Wilting \& Vringer 2010).

Given that $1 \mathrm{O}$ analysis takes into consideration the links existing between sectors and components of the final demand within a single economy to analyse the relations 
between various countries and/or regions, it is necessary to use multi-regional inputoutput (MRIO) analysis. This MRIO approach extends the geographical area and takes into account the relations existing with other economies' demand sectors and components (Gao et al. 2020).

Specifically, and following the naming of the literature (Zhang et al. 2019; AlmazánGómez et al. 2019), $m$ regions are considered within which $n$ sectors exist. Hence, the MRIO model has $m x n$ linear equations, $R$ being the superscript, $S$ the regions, $i$ being the subscripts, and $j$ the sectors:

$$
x_{i}^{R}=\sum_{S=1}^{m} \sum_{j=1}^{n} x_{i j}^{R S}+\sum_{S=1}^{m} y_{i}^{R S}
$$

Being $x_{i}^{R}$ the total production of the sector $i$ in the region $R, x_{i j}^{R S}$ the intermediate inputs of the sector $i$ in the region $R$ which are used by the sector $j$ in the region $S$, and $y_{i}^{R S}$ is the final demand of the sector $i$ in the region $R$ for region $S$.

Taking into account that $a_{i j}^{R S}=\frac{x_{i j}^{R S}}{x_{j}^{S}}$, are technical coefficients which show the requirements of the intermediate inputs of the sector $i$ of the region $R$ regarding the total production of the sector $j$ of region $S$, equation (1) can also be expressed as:

$$
x_{i}^{R}=\sum_{S=1}^{m} \sum_{j=1}^{n} a_{i j}^{R S} x_{j}^{S}+\sum_{S=1}^{m} y_{i}^{R S}
$$

This equation (2) can be expressed in matrix terms, that is to say:

$$
X=A X+Y
$$

Operating obtains: $\quad X=(I-A)^{-1} Y$

Where $L=(I-A)^{-1}$ is the inverse matrix of Leontief of dimension $m^{*} n \times n^{*} m$, whose elements, $l_{i j}^{R S}$ are the requirements of production of the sector $i$ of region $R$ necessary to satisfy one unit of final consumption of the sector $j$ of the region $S$. 
If we multiply both members of equation (4) by $e$, the diagonal matrix of emissions coefficients, whose elements, $e_{i}^{R}=\frac{e_{i}^{R}}{x_{i}^{R}}$ represent the emissions generated per unit of production of the sector $i$ in the region $R$, one obtains the matrix $E$ :

$$
E=e \cdot L \cdot Y
$$

Specifically, the sum of the elements of the matrix $E$ by columns permits obtaining the $\mathrm{CF}$ and by rows the emissions from the EPP. Therefore, from equation (5), one can obtain the CF and the EPP of a specific region $S$, in general or by sectors:

$$
\begin{gathered}
C F^{S}=\sum_{R=1}^{m}\left(\sum_{j=1}^{n} \sum_{i=1}^{n} E_{i j}^{R S}\right) \\
E P P^{S}=\sum_{S=1}^{m}\left(\sum_{j=1}^{n} \sum_{i=1}^{n} E_{i j}^{R S}\right)
\end{gathered}
$$

The following components are defined for the interpretation of the analysis of the CF from the point of view of the sectors:

Direct Domestic Emissions: those $\mathrm{CO}_{2}$ emissions embodied in the products and services generated by and for the same reference sector, generated in a specific country: $E D D_{i}^{S}=E_{i j}^{R S} \quad$, for which $i=j$ y $R=S$

Indirect Domestic Emissions: those $\mathrm{CO}_{2}$ emissions embodied in the products and services generated by other sectors within the country and consumed by the sector analysed. The sum of the direct and indirect domestic emissions is the domestic CF.

$$
E I D_{i}^{S}=\sum_{i=1}^{n} E_{i j}^{R S}, \text { whenever } R=S \text { and for all } i \neq j
$$

External Indirect Emissions: those emissions embodied in the sector's imports. These emissions are the $\mathrm{CF}$, without including what is domestic.

$$
E I E_{j}^{S}=\sum_{R=1}^{m}\left(\sum_{i=1}^{n} E_{i j}^{R S}\right), \text { whenever } R \neq S
$$


At this point it is desirable to establish that the global emissions do not change according to the approach used, "consumption-based" or "production-based", as only the way in which these emissions are assigned to each country changes (Wilting \& Vringer 2010; Dolter \& Victor 2016).

On the other hand, for a specific country or region, the Emissions Trade Balance (ETB) can be determined, showing the difference between the emissions embodied in the exported national production minus the emissions embodied in the imports of goods and services for national consumption. This would be given by the following equation:

$$
E T B^{S}=E P P^{S}-C F^{S}
$$

Finally, considering the definition of Román et al. (2016), the total emissions embodied in the international trade (EEIT) of a specific country or region $S$ can be analysed as the difference between the emissions embodied in the exports (EEE) and the imports (EEI):

$$
E E I T=E E E^{S}+E E I^{S}=\sum_{R=1}^{m}\left(\sum_{j=1}^{n} \sum_{i=1}^{n} E_{i j}^{R S}\right)+\sum_{S=1}^{m}\left(\sum_{j=1}^{n} \sum_{i=1}^{n} E_{i j}^{R S}\right), \text { whenever } R \neq S
$$

EEIT, enables determining the global emissions generated as a consequence of the international trade (including exports and imports) of a certain country or region. The environmental pressure that this country or region has at the global level is obtained, measured in terms of emissions.

\subsection{Database}

Monetary tables (based on a mix of basic-price and purchaser-price data) and the satellite accounts from EORA have been used. Gross information of the United Nations System of National Accounts and the databases of COMTRADE, Eurostat, IDE / JETRO and various national agencies was obtained for the generation of the base (Lenzen et al. 2012; 2013).

The harmonised classification that the simplified version (Eora26) has defined with 26 sectors (See Table A1) and 187 countries/regions (See Table A2) has been used for the calculations. As a consequence of the aggregation of sectors, differences can arise between the complete and simplified EORA bases. However, this effect is less 
pronounced for the level that is being considered in this study (Steen-Olsen et al., 2014; 2016).

For the presentation of the results the information for 6 regions has been aggregated (See Table A2): ECU (Ecuador), BRICS (Brazil, Russia, India, China and South Africa), LAC (Latin America and the Caribbean), NA (North America), EU (the European Union), RoW (Rest of the World) and 8 sectors (See Table 1): primary, secondary, electricity, gas and water, construction, hotels and trade, transport, other services and re-exportation and re-importation. The regions have been defined according to Ecuador's main trade partners in 2015, taking into account that this type of consideration is frequent in the literature (Tukker et al. 2016; Dolter \& Victor 2016; Wilting \& Vringer 2010). The 8-sector scale classification has been based on the studies of Dolter and Victor (2016), Minx et al. (2010), and Turner et al. (2008), establishing the necessary specifications according to Ecuador's particularities.

The present study centres its analysis on three years: 2000, 2008 and 2015. The year 2000 is a reference of the new millennium, when Ecuador adopted the dollar currency. This followed one of the greatest crises that the country has had to face and whose origin was the financial sector, underlining the impact in 1999. The year 2008 is an intermediate reference, defining the situation and starting point of the constitutional change, considering all the economic, social and especially environmental implications which this entailed. Finally, the analysis for the year 2015 is determined as a postconstitutional change, being the last reference year for the country available in the database.

For the reference years, the information of $\mathrm{CO}_{2}$ emissions for the environmental extension of the MRIO was taken from the satellite accounts of EORA and, failing this, from the EDGAR (Emission Database for Global Atmospheric Research) database version 4.3.2. (Olivier et al. 2016).

\section{Results.}

The analysis of results has allowed us to present the evolution of the four magnitudes; that is, the Carbon footprint (CF), the Emissions based on the Production Principle (EPP), the Emissions Trade Balance (ETB) and the Emissions Embodied in International Trade 
(EEIT), both at the national level and in the country's relation with the regions considered, and at the sectoral level, considering also the links with the distinct regions. The general results are presented in Table B1 (Annex B).

\subsection{National Level Analysis}

The results concerning the volume of emissions of Ecuador according to the two perspectives (consumer and producer), in the three years of analysis, are shown in Table 1.

The CF of the country, that is to say the $\mathrm{CO}_{2}$ emissions under the $\mathrm{ECP}$, went from $18554.02 \mathrm{Gg}$ in 2000 to $31814.24 \mathrm{Gg}$ in 2008 (71.47\%) and to $45506.01 \mathrm{Gg}$ in 2015 (43.04\% with respect to 2008), resulting in a growth of $145.26 \%$ compared to 2000 .

On the other hand, the emissions under the EPP had a lower growth. In 2000 they were $19498.95 \mathrm{Gg}$, had grown by 58.38\% in 2008 (30882.86 Gg) and for the year 2015 had risen by $35.19 \%$ with respect to 2008 (a growth of $114.11 \%$ between 2000 and 2015), reaching $41749.09 \mathrm{Gg}$.

Table 1: Ecuador's $\mathrm{CO}_{2}$ emissions by destination and origin

\begin{tabular}{|c|c|c|c|c|c|c|}
\hline & \multicolumn{3}{|c|}{ Gigagrams } & \multicolumn{3}{|c|}{ Variation (\%) } \\
\hline & 2000 & 2008 & 2015 & 2000-2008 & 2008-2015 & 2000-2015 \\
\hline $\begin{array}{l}\text { Carbon Footprint: } \\
(1)+(2)\end{array}$ & 18554.02 & 31814.24 & 45506.01 & $71.47 \%$ & $43.04 \%$ & $145.26 \%$ \\
\hline $\begin{array}{l}\text { ECU: domestic } \\
\text { emissions (1) } \\
\text { Emissions of }\end{array}$ & 14039.93 & 22721.32 & 33322.58 & $61.83 \%$ & $46.66 \%$ & $137.34 \%$ \\
\hline Imports $(2)^{* 1}$ & 4514.09 & 9092.92 & 12183.43 & $101.43 \%$ & $33.99 \%$ & $169.90 \%$ \\
\hline LAC (3) & 1126.29 & 2414.86 & 3356.06 & $114.41 \%$ & $38.98 \%$ & $197.98 \%$ \\
\hline NA (4) & 1407.59 & 2401.97 & 3145.64 & $70.64 \%$ & $30.96 \%$ & $123.48 \%$ \\
\hline EU (5) & 528.97 & 899.33 & 1083.43 & $70.02 \%$ & $20.47 \%$ & $104.82 \%$ \\
\hline BRICS (6) & 700.39 & 2159.47 & 2975.79 & $208.33 \%$ & $37.80 \%$ & $324.88 \%$ \\
\hline RoW (7) & 750.86 & 1217.28 & 1622.52 & $62.12 \%$ & $33.29 \%$ & $116.09 \%$ \\
\hline Emisiones $\mathrm{CO}_{2} \mathrm{EPP}$ & 19498.95 & 30882.86 & 41749.09 & $58.38 \%$ & $35.19 \%$ & $114.11 \%$ \\
\hline domestic & & & & & & \\
\hline $\begin{array}{l}\text { emissions } \\
\text { Emissions of }\end{array}$ & 14039.93 & 22721.32 & 33322.58 & $61.83 \%$ & $46.66 \%$ & $137.34 \%$ \\
\hline Exports (8) & 5459.02 & 8161.54 & 8426.51 & $49.51 \%$ & $3.25 \%$ & $54.36 \%$ \\
\hline LAC & 1629.07 & 2563.25 & 3146.58 & $57.34 \%$ & $22.76 \%$ & $93.15 \%$ \\
\hline NA & 1676.28 & 2293.92 & 2021.90 & $36.85 \%$ & $-11.86 \%$ & $20.62 \%$ \\
\hline EU & 826.66 & 1303.64 & 1098.19 & $57.70 \%$ & $-15.76 \%$ & $32.85 \%$ \\
\hline BRICS & 291.21 & 622.98 & 727.12 & $113.93 \%$ & $16.71 \%$ & $149.69 \%$ \\
\hline RoW & 1035.80 & 1377.76 & 1432.72 & $33.01 \%$ & $3.99 \%$ & $38.32 \%$ \\
\hline
\end{tabular}




\begin{tabular}{lrrrrrr} 
ETB $=(8)-(2)$ & 944.93 & -931.37 & -3756.92 & $-198.57 \%$ & $303.37 \%$ & $-497.59 \%$ \\
EEIT $=(8)+(2)$ & 9973.11 & 17254.46 & 20609.93 & $73.01 \%$ & $19.45 \%$ & $106.66 \%$ \\
\hline
\end{tabular}

Source: Own elaboration.

$*^{11}(2)=(3)+(4)+(5)+(6)+(7)$

Notwithstanding, the behaviour of the emissions under the consumption and production principal has not been the same in the three years considered. In 2000, Ecuador's CF was almost 5\% less than the $\mathrm{CO}_{2}$ under the EPP, while for 2008 and 2015 the relation is reversed, the CF being greater than the EPP emissions by $3 \%$ and $9 \%$, respectively, for those years. Specifically, the emissions embodied in the imports went from $4514.09 \mathrm{Gg}$ in 2000 to $12183.43 \mathrm{Gg}$ in 2015 (a growth of 169.90\%), while the emissions embodied in exports increased from $5459.02 \mathrm{Gg}$ to $8426.51 \mathrm{Gg}$ (an increase of $54.36 \%)$. Thus, Ecuador's ETB went from $944.93 \mathrm{Gg}$ in 2000 to a value of $-3756.92 \mathrm{Gg}$ in 2015.

The difference between the CF and the EPP can be mainly explained by two factors: $a$ change in the trade balance of goods, and the distinct intensity of emissions of imported and exported goods (Wilting \& Vringer 2010).

In the period analysed, the increase of the emissions due to imports (169.90\%) has grown three times more than those as a result of exports (54.63\%). In particular, Ecuador's current account balance began to be negative from 2007-2008, specifically by 1366.5 million dollars (Banco Mundial 2020). Therefore, the greater volume of imports is one explanatory factor of why the CF is higher than the EPP from this year. However, the accelerated growth of the $\mathrm{CO}_{2}$ emissions embodied in imports has been abruptly greater than that expressed in monetary terms, giving a relation of 3 to 1 for the 20082015 period (a growth of imports in monetary terms of $11.25 \%$, compared to a growth of imports in terms of emissions of approximately 34\%) (Banco Mundial 2020).

As to the local $\mathrm{CO}_{2}$ emissions derived from the consumption of national production (domestic emissions), they rose from $14039.93 \mathrm{Gg}(2000)$ to $22721.32 \mathrm{Gg}$ (2008) and to $33322.58 \mathrm{Gg}$ (2015), growing 137.34\% between 2000 and 2015. These domestic emissions are more than $70 \%$ of the CF and of the EPP approach of Ecuador during all the period analysed. 
Finally, having analysed the emissions due to imports and exports as a whole, that is to say the EEIT, Ecuador's participation in world trade means that its world environmental pressure has gone from representing $9973.11 \mathrm{Gg}$ in 2000 to $20609.93 \mathrm{Gg}$ in 2015. This is an increase of $106.66 \%$.

\subsection{Analysis of the link between Ecuador and the Regions}

The data relative to the CF show that in 2000 the region which most affected the volume of emissions embodied in the imports of Ecuador was North America (NA) with 1407.59 Gg (7.56\% of the total). However, in 2008, Latin America and the Caribbean (LAC) was the most important region with $2414.86 \mathrm{Gg}(7.59 \%$ of the total), maintaining its position in 2015 with $3356.06 \mathrm{Gg}$ (7.37\% of the total). Likewise, it is important to underscore the growing importance of the carbon emissions embodied in the imports from the BRICS nations (324.88\% de 2000 a 2015), which represent $24 \%$ of the total $\mathrm{CO}_{2}$ emissions for 2015.

When we analyse the data relative to the EPP in 2000, the regions which had more weight in the volume of emissions embodied in Ecuador's exports are NA and LAC. This situation is reversed in 2008 and 2015, LAC being the region of origin with a greater volume of emissions embodied in the exports $(3146.58 \mathrm{Gg})$, far above NA (2021.90 Gg) and the BRICS countries (1432.72 Gg). In the same way, the volume of emissions embodied in Ecuador's exports significantly increase in the BRICS for the period analysed (150\% approximately).

Figures 1 and 2 show the relative weight of each of the regions as importers (destination) or exporters (origin) of emissions embodied towards and from Ecuador. 
Emissions Embodied in Imports.

(\% of Total of Imports)

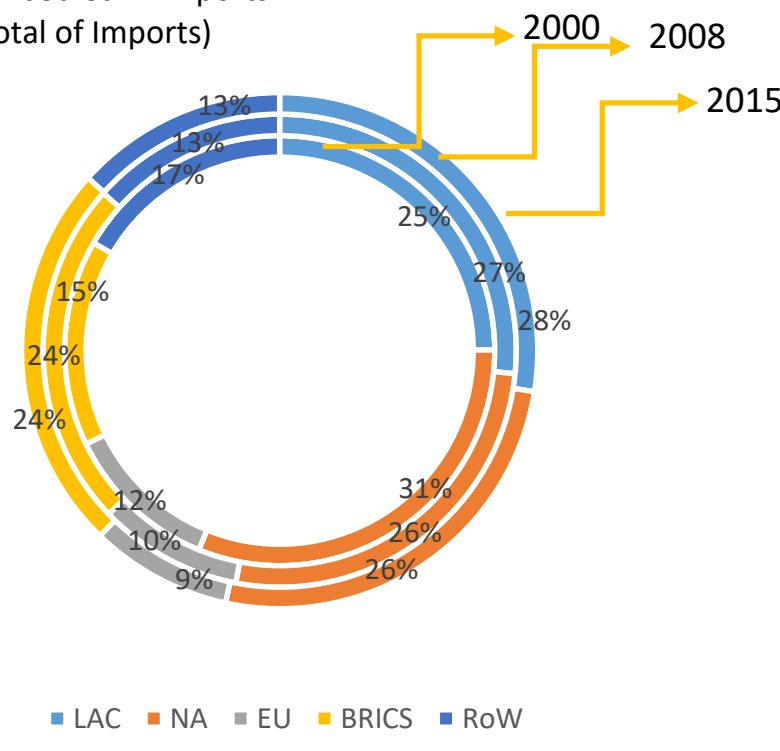

Figure 1: Emissions Embodied in Imports of Ecuador for Region of Origin (\% of Total of Imports).

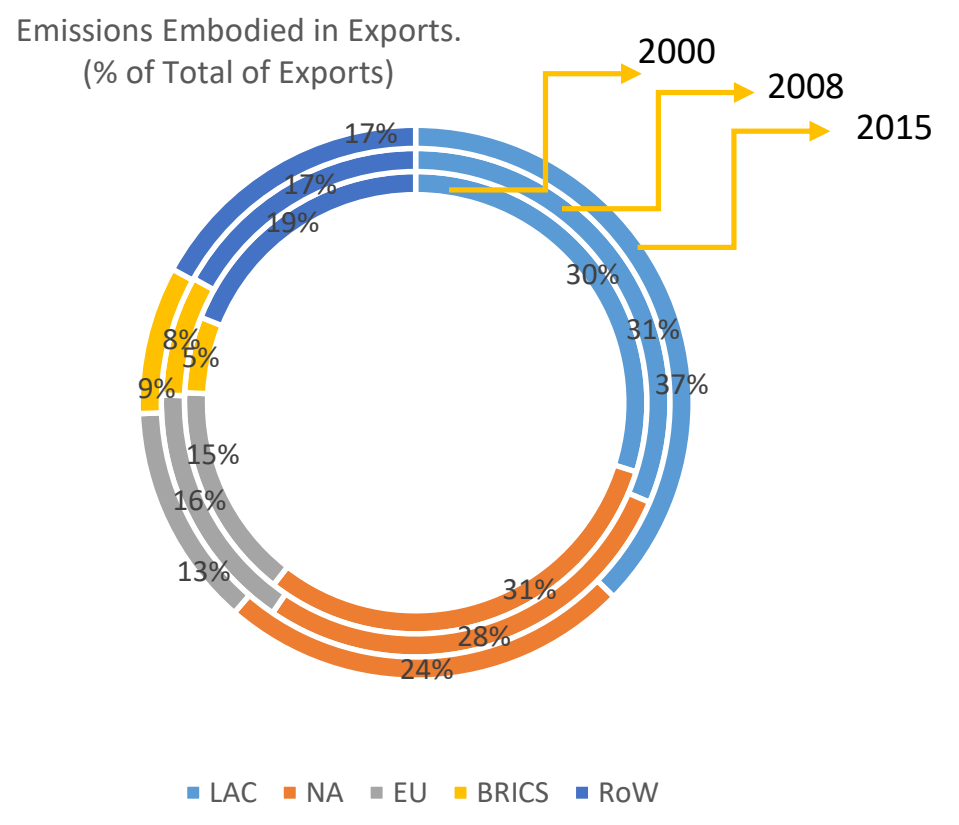

Figure 2: Emissions Embodied in Exports of Ecuador for Region of Origin (\% of Total of Exports)

We highlight the increase of the participation of the BRICS nations as to the origin region of the emissions embodied in Ecuador's imports, reaching a weight of $24 \%$ of the 2015 
total. On the contrary, its weight as a destination region of the emissions embodied in Ecuador's exports has been maintained at minimum levels. This would in part explain the growing gap between the CF and the emissions calculated under the EPP for this zone. Another interesting aspect is the growth in the weight which the LAC region has as the destination of the emissions embodied in Ecuador's exports, which goes from $30 \%$ to $37 \%$.

On the other hand, Figure 3 shows the weight emissions embodied in Ecuador's imports and the exports with each region, according to the reference year. Regarding the BRICS countries, Ecuador has been a net importer in the three years considered. As to regions such as LAC and the Rest of the World (RoW), Ecuador has gone from being a net exporter in 2000 and 2008 to being a net importer in 2015. Ecuador has reversed the previous trend with NA, going from being a net exporter in 2000 to a net importer in 2008 and 2015. In 2015, Ecuador was a net importer of emissions embodied from all the regions considered, except the case of the European Union (EU). For the latter, Ecuador has continued being a net exporter of emissions, although the gap is increasingly smaller.

Figure 3: Exchange of Emissions between Ecuador and the different Regions

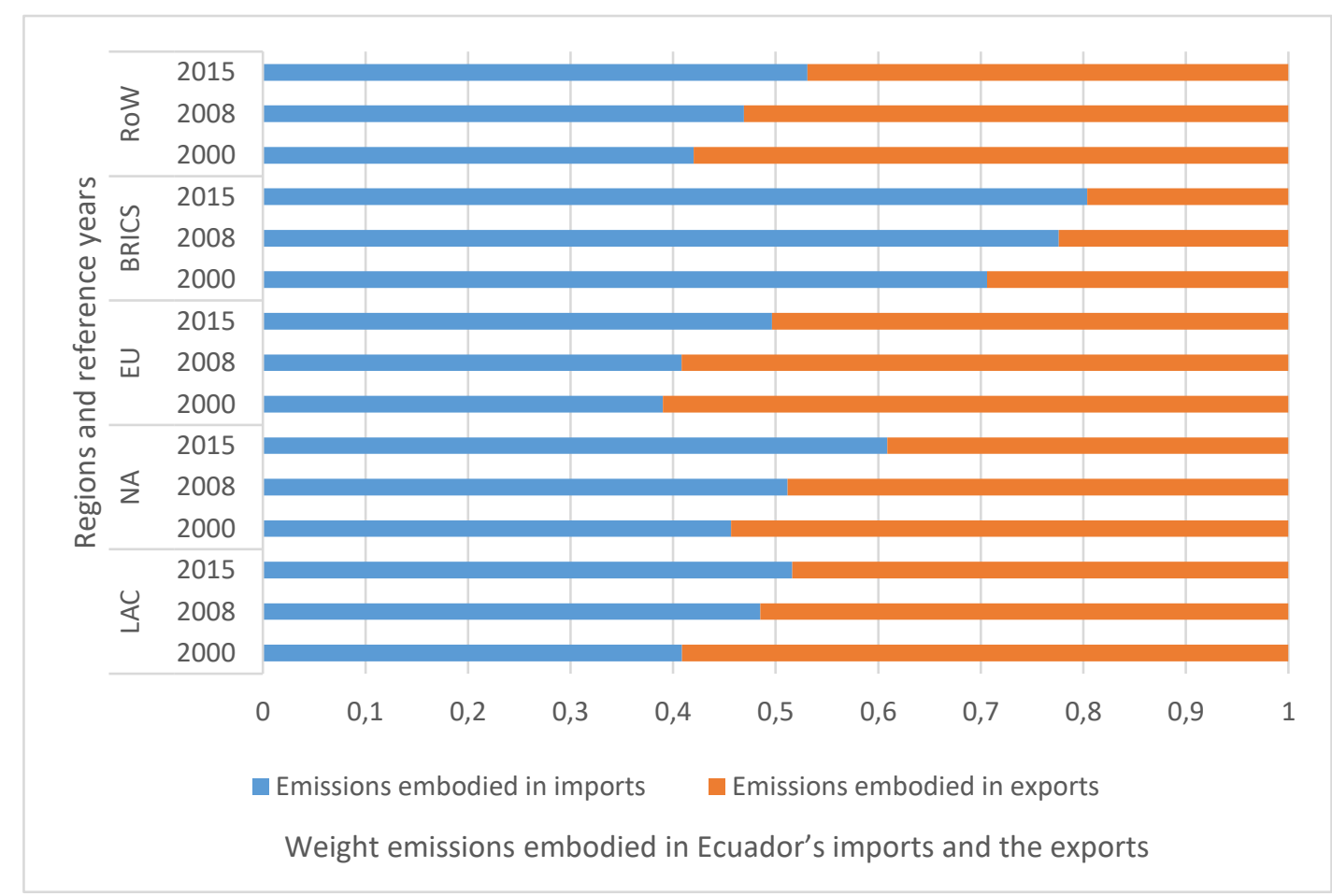


Figure 4 shows the total environmental pressure generated by Ecuador's international trade with the distinct regions considered, according to the years of reference and distinguishing between those due to exports and to imports. The results show that LAC, BRICS, NA and the RoW have been gaining weight in Ecuador's EEIT between 2000 and 2015, especially due to imports. In the case of the EU, the volume of EEIT has been maintained since 2008, those due to imports increasing. In particular, it is to be emphasised that, from 2008, LAC has been the region with which the trade relations have generated a greater environmental stress. This is without ignoring NA's considerable participation and the abrupt change that has taken place with the BRICS nations.

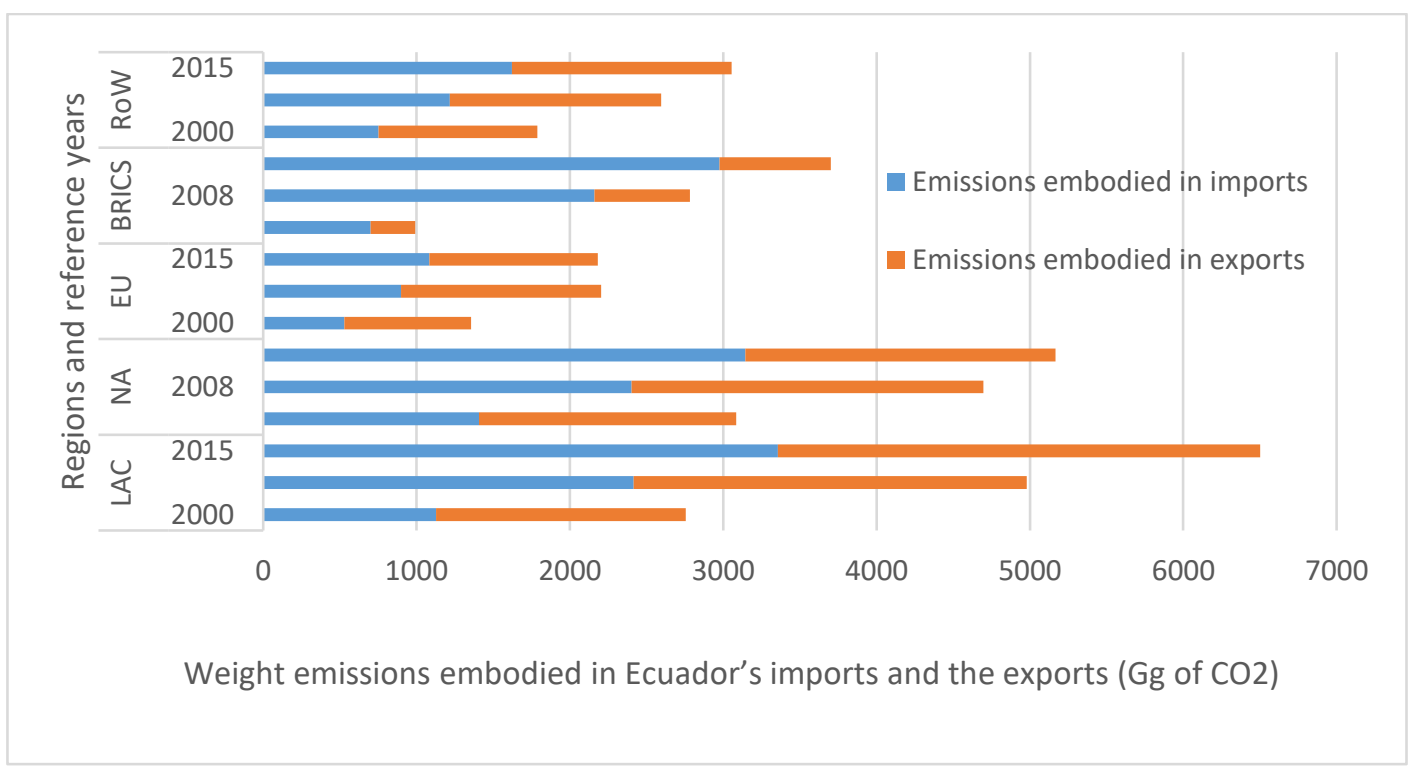

Figure 4: Total Emissions Included in Ecuador's Trade with the distinct Regions

\subsection{Sectoral analysis of emissions trade in Ecuador.}

Table 2 presents the results for each of the variables considered; that is, CF, EPP and ETB corresponding to Ecuador, detailed for each of the sectors and years considered in the analysis. 
Table 2: Ecuador's $\mathrm{CO}_{2}$ emissions by Sectors (CF, EPP, ETB)

\begin{tabular}{|c|c|c|c|c|c|c|c|c|c|}
\hline \multirow{2}{*}{ Sectors } & \multicolumn{3}{|c|}{$\mathrm{CF}$} & \multicolumn{3}{|c|}{ EPP } & \multicolumn{3}{|c|}{ ETB } \\
\hline & 2000 & 2008 & 2015 & 2000 & 2008 & 2015 & 2000 & 2008 & 2015 \\
\hline Primary Sector & 714.72 & 1090.80 & 1600.68 & 2773.96 & 4043.11 & 5606.87 & 2059.23 & 2952.31 & 4006.19 \\
\hline Secondary Sector & 5945.54 & 9953.02 & 14252.44 & 4090.63 & 5529.21 & 8034.65 & -1854.91 & -4423.81 & -6217.79 \\
\hline $\begin{array}{l}\text { Electricity, Gas } \\
\text { and Water }\end{array}$ & 1114.51 & 2173.93 & 3215.46 & 2429.60 & 5335.80 & 6838.70 & 1315.09 & 3161.87 & 3623.24 \\
\hline Construction & 1642.73 & 2742.35 & 3620.43 & 360.28 & 573.49 & 770.64 & -1282.45 & -2168.86 & -2849.79 \\
\hline Hotels and Trade & 260.10 & 478.09 & 651.50 & 88.98 & 167.12 & 310.95 & -171.12 & -310.97 & -340.54 \\
\hline Transport & 7736.99 & 12486.72 & 18140.68 & 9595.30 & 14684.00 & 18990.00 & 1858.31 & 2197.28 & 849.32 \\
\hline Other Services & 1101.68 & 2817.96 & 3920.01 & 160.20 & 550.14 & 1197.28 & -941.48 & -2267.82 & -2722.73 \\
\hline $\begin{array}{r}\text { Re-export \& Re- } \\
\text { import }\end{array}$ & 37.75 & 71.37 & 104.82 & 0.00 & 0.00 & 0.00 & -37.75 & -71.37 & -104.82 \\
\hline TOTAL & 18554.02 & 31814.24 & 45506.01 & 19498.95 & 30882.86 & 41749.09 & 944.93 & -931.37 & -3756.92 \\
\hline
\end{tabular}

From the CF point of view, the transport sector and the secondary sector are those which are generators of a greater volume of $\mathrm{CO}_{2}$ emissions: $18140.68 \mathrm{Gg}$ ( $40 \%$ of the total) and $14252.44 \mathrm{Gg}$ (31\% of the total), respectively, in the year 2015 . In the period analysed, an increase of its footprint of more than double has occurred in all the sectors. This increase has been especially marked in the sectors of Other services, of Electricity and of Trade which, setting out from relatively moderate emissions levels, have experienced growth rates between 2008 and 2015 of $255.8 \%, 188.5 \%$ and $150.5 \%$, respectively.

On the other hand, from the EPP perspective we identify the transport sector as the most pollutant during all the period of analysis, followed by the secondary sector. In turn, the primary and electricity, gas and water sectors stand out for their remarkable participation in the emissions of 2015, attaining a volume of $5606.87 \mathrm{Gg}$ and $6838.7 \mathrm{Gg}$, respectively.

From the ETB perspective it is noted that the secondary sector, that of construction, that of trade and that of other services are net importers of emissions compared to the primary, electricity, gas, water and transport sectors which are net exporters of emissions in all the period considered. This shows the important dependence of these sectors on imports.

To go deeply into the behaviour of the emissions of the sectors according to their origin, Figure 5 shows Ecuador's CF in the last three years analysed, broken down into the direct 
emissions and domestic indirect as well as the indirect imports. The direct (DE) and domestic indirect emissions (DIE) show the weight of the emissions of the sectors caused by the consumption of national production, either generated by the sector itself or by other national sectors. For their part, the imported indirect emissions (IEE) are the emissions caused by a specific sector's import need.

As shown in Figure $5 \mathrm{a}$, more than $70 \%$ of the emissions generated by the transport sector are direct; that is to say, they are emissions embodied in the products and services generated by and for the transport in the country itself. Nevertheless, the growth experienced by the imported indirect emissions (197\%) between 2000 and 2015 stands out. Also, the electricity sector's CF is mainly due to the direct emissions (90\%) those that are indirect being marginal (Figure 5e).

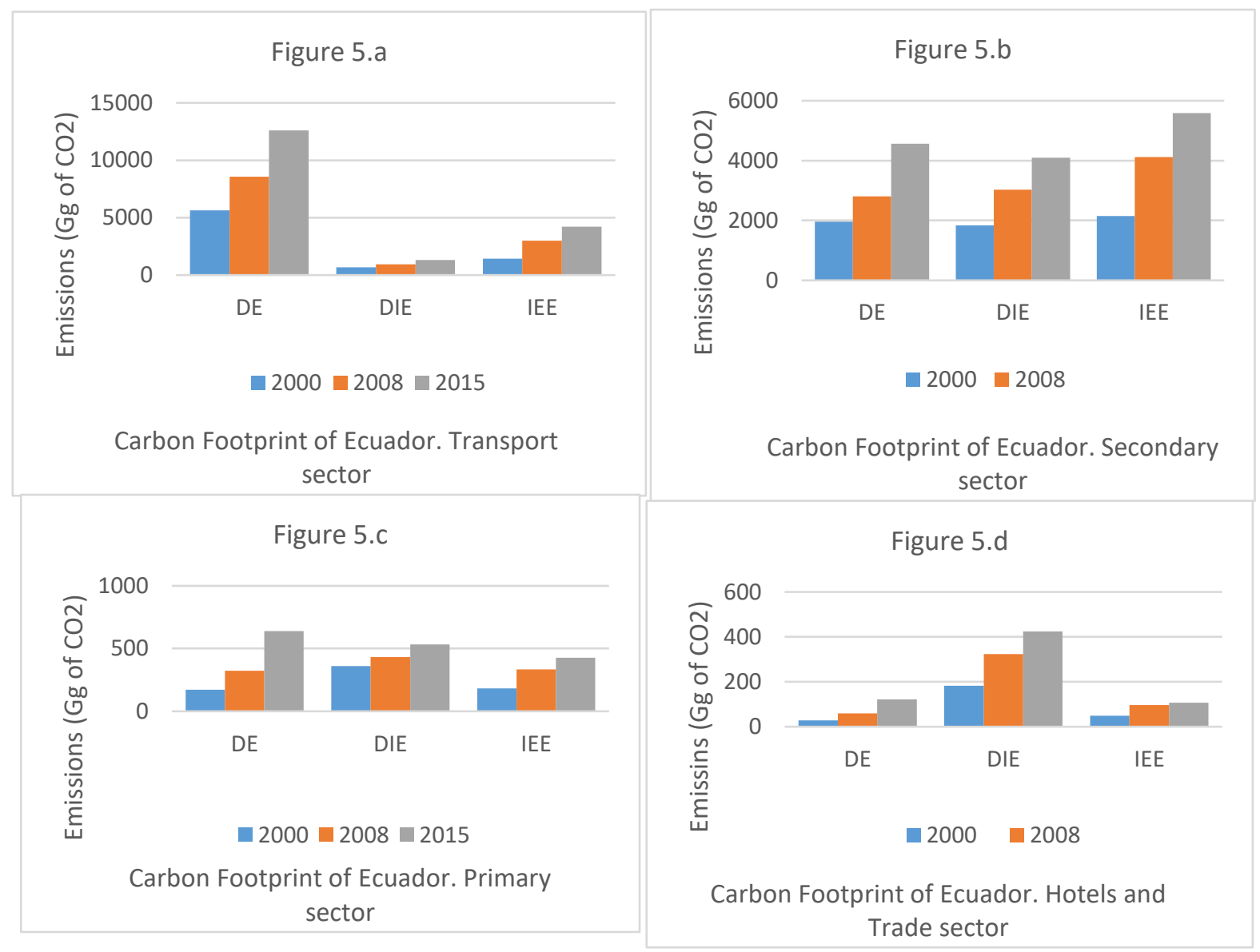




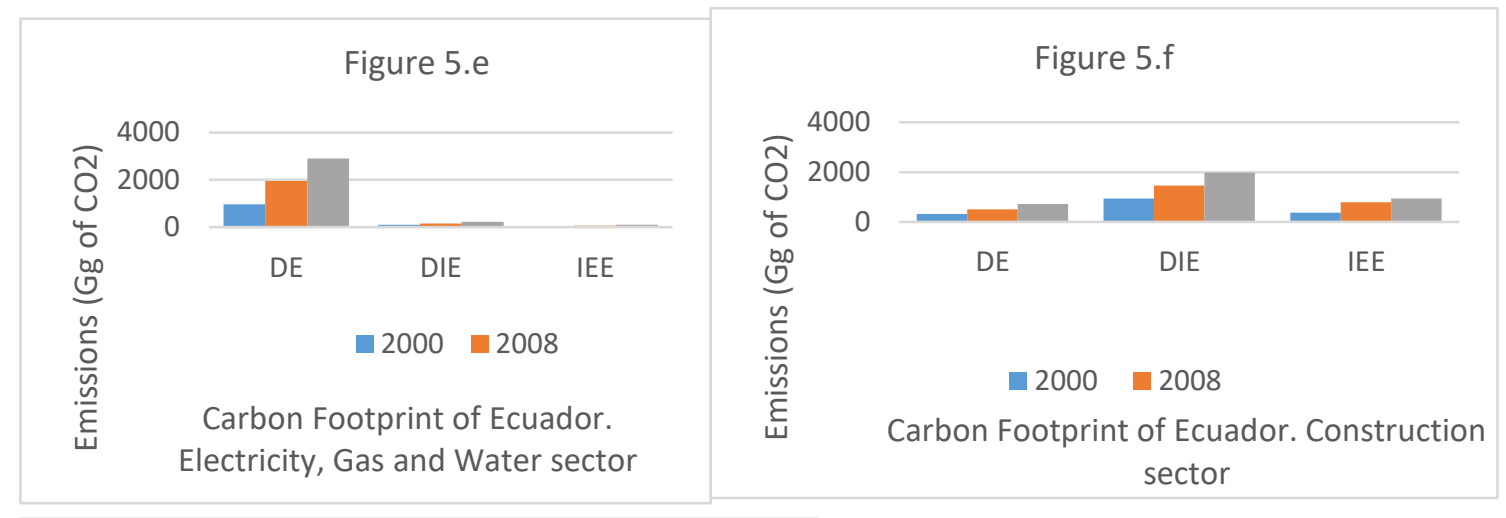

Figure 5: Carbon footprint of Ecuador by sectors and reference years (Gg of CO2).

Figure $5 b$ shows the secondary sector, one of the most pollutant in Ecuador. The CF is fairly distributed among the three types: direct, domestic indirect and imported indirect emissions although the latter should be highlighted due to its having shown an important increase (160\%) between 2000 and 2015. This behaviour has also been reported in the case of the primary sector as can be seen in Figure $5 c$, where the imported indirect emissions increased by 132\% between 2000 and 2015 (see Table B2).

As to the sectors in which Ecuador's footprint has grown most, similarities are seen between "Other services" and "Hotels and Trade", in which more than half the CF is generated by domestic indirect emissions. That is to say, that they are emissions embodied in the products and services generated by other sectors within Ecuador, but they are consumed in the two sectors, respectively. This pattern is also seen in the case of the construction sector, though here we must emphasise the significant growth of the imported indirect emissions (154\%) between 2000 and 2015 (Figure 5f).

Figures $6 a$ and $6 b$ represent the breakdown by geographic zones of the imported indirect footprint (see the detail in Table B3 of the Annex). In this case, the behaviour of 
the two sectors with the greatest footprint has been different. For 2015, the analysis of the imported indirect emissions for the transport sector shows that $40 \%$ come from the NA and $31 \%$ from LAC. Since in 2000 LAC only represented $26 \%$ of imported indirect emissions of the transport sector, these new percentages show the importance that the LAC region is gaining in Ecuador's international trade.

In 2015, in the case of the secondary sector, the origin of the imported indirect emissions is as follows: $35 \%$ from the emerging countries region (BRICS), $25 \%$ from LAC and $17 \%$ from NA. If these percentages are compared with those of 2000 , some differences arise due to the importance that the BRICS region is attaining in the imported indirect emissions of this sector, parallel to a diminishing in the relative weight of the NA region. These results can be analysed from the perspective of this sector's CF, being the most pollutant of all the sectors. As has been highlighted previously, the indirect imported emissions of this sector have increased by $160 \%$ between 2000 and 2015 and represent almost $40 \%$ of the total CF. This is why the changes in the relative weight that the regions have in these emissions have to be analysed in detail.

The NA, LAC and BRICS regions are those which have a greater weight in Ecuador's imported indirect emissions, both in the two sectors mentioned and in that of Construction and that of Other services, as can be seen in Figures $6 \mathrm{a}$ and $6 \mathrm{~b}$.

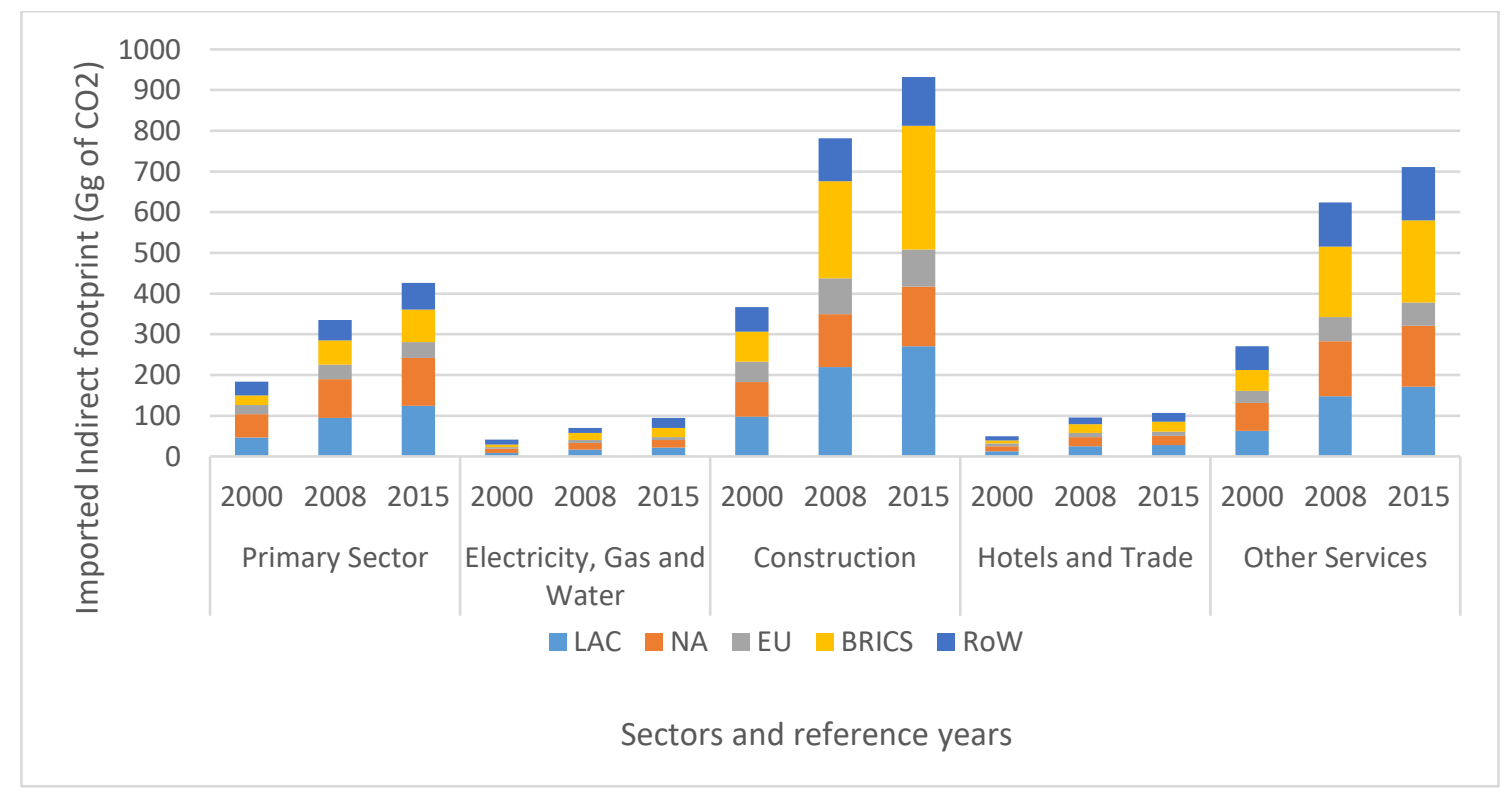




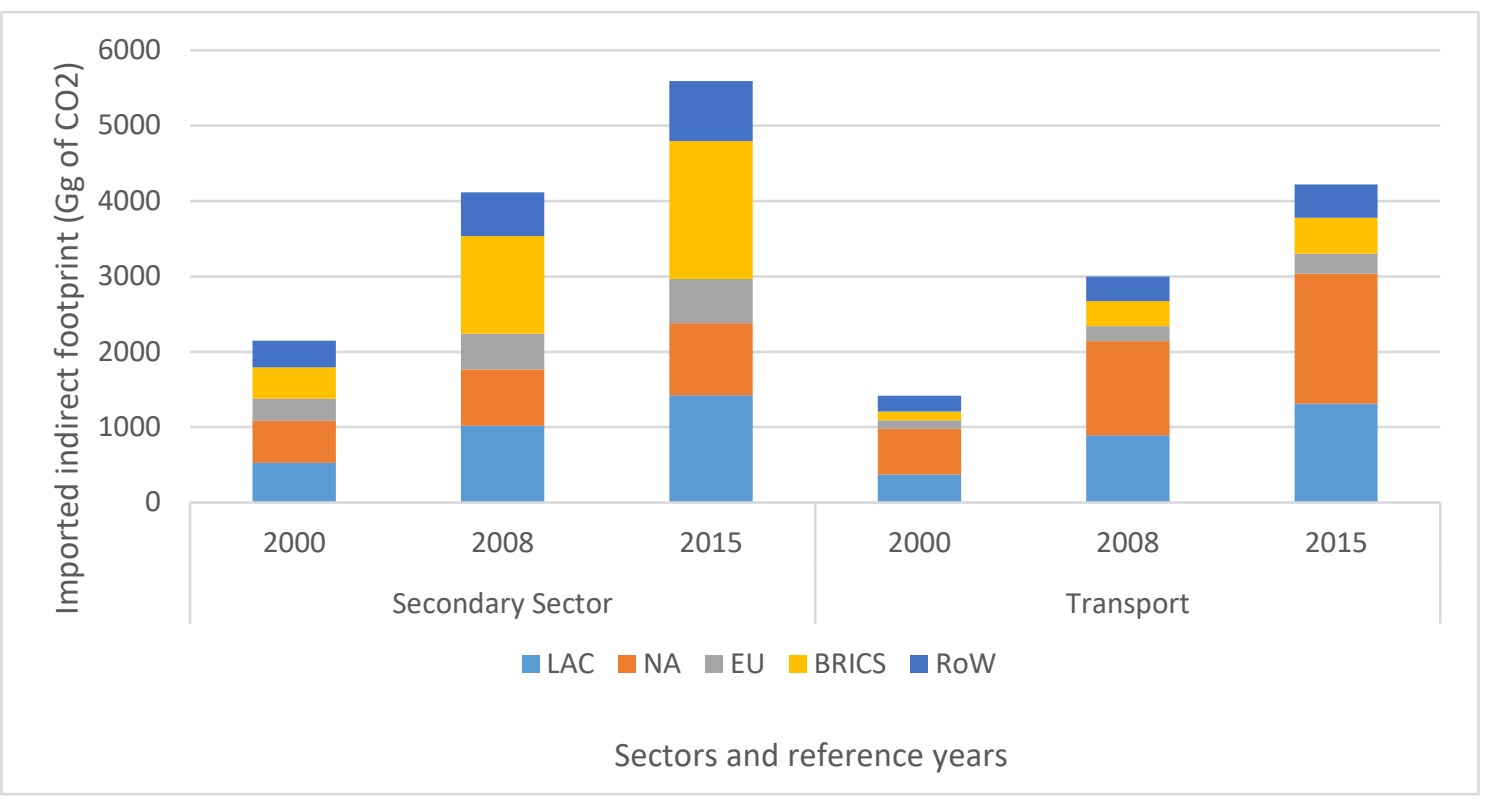

Figures $6 \mathrm{a}$ and $6 \mathrm{~b}$ : Imported indirect footprint by sectors and reference years.

\section{Discussion}

The analysis of $\mathrm{CO}_{2}$ emissions for Ecuador shows an accelerated growth from both the producer's and the consumer's perspective, increasing $145.3 \%$ and $114.1 \%$, respectively, between 2000 and 2015. This major growth of emissions embodied in consumption is due to the strong growth experienced in the 2000-2008 expansion stage (71\%), much more tempered in the $2008-2015$ period (43\%).

On the other hand, accounting for emissions from the consumer's and producer's point of view shows that the domestic $\mathrm{CO}_{2}$ emissions represented $76 \%$ and $72 \%$, respectively, of the total emissions calculated in 2000, and were $73 \%$ and $80 \%$, respectively, in 2015 . This data implies that the greatest efforts that Ecuador must make to move towards a low carbon economy has to be centred on local production and national consumption.

Given the important relative weight of domestic emissions in the total calculation of Ecuador's emissions, both calculated according to the CF or EPP approach, the particular study of those sectors responsible for these emissions is required. The analysis of the sectors which have a greater relative weight in Ecuador's domestic emissions throughout the period analysed shows that these are the secondary and transport sectors, representing $26 \%$ and $42 \%$, respectively, in 2008 and 2015 . The two sectors 
explain more than $60 \%$ of the domestic emissions. In turn, the increase of the relative importance of the sector Other services in the domestic emissions total should be stressed. This went from representing 6\% in 2000, to $10 \%$ in 2008 and 2015.

On the other hand, it is seen that the CF is higher than the emissions calculated under the EPP in the years 2008 and 2015, Ecuador becoming a net emissions importer country. The growing gap in the ETB is due not only to Ecuador's trade deficit since 2008, but also to the influence of aspects related with the change of its trade patterns, such as the increase of trade relations with the BRICS region. This trend is consolidated for China, as Samanamud (2014) reflects, pinpointing the growth between 2001 and 2011 of the trade relations between the two countries. Lapeña and Czubala (2018) are in line with this when they study the trade relations between the two countries for 2016.

This fact coincides with the results attained by Peters et al. (2011), who show that the $\mathrm{CO}_{2}$ emissions embodied in trade with countries which are not part of Annex $\mathrm{B}$ of the Kyoto Protocol have had a quick growth (21.5\% from 1900 to 2008). On the other hand, numerous authors, such as Davis and Caldeira (2010), Deng and Xu (2017) and Tukker et al. (2016) have identified China, Russia, South Africa and India among the countries which are the main net exporters of $\mathrm{CO}_{2}$ to the world.

At the sectoral level, it is noted that the secondary and transport sectors represent approximately more than $30 \%$ and $40 \%$, respectively, of Ecuador's CF in the period analysed. Nonetheless, the emissions embodied in the exports only explain $46 \%$ and $35 \%$ in 2015 . The two sectors justify more than $80 \%$ of these emissions and are determinants of their evolution in the 2000-2015 period. Specifically, in the case of the secondary sector it is worth highlighting the significant relative weight which this represents (62\%) of the emissions embodied in the imports from the BRICS countries in 2015. This percentage has increased in the period studied, being $59 \%$ in 2000 . In turn, in 2015 , the transport sector is responsible for $55 \%$ and $39 \%$ of the emissions embodied in the imports from NA and LAC, respectively. This percentage has increased considerably in the period studied, as in 2000 it was around $43 \%$ and $33 \%$, respectively.

In the international area, considering both the emissions embodied in Ecuador's imports and in its exports, this country generated $20609.93 \mathrm{Gg}$ of $\mathrm{CO}_{2}$ emissions in 2015. A 
substantial increase took place between 2000 and 2015, due mainly to the increase of imports, and within these to the rise of almost $200 \%$ of those from LAC and more than $300 \%$ of the imports from the BRICS. The significant weight of the secondary and transport sectors in Ecuador's domestic emissions place these two sectors in Ecuador's spotlight, as do the emissions embodied in its imports, especially from emerging countries (BRICS), from NA and LAC, whose emissions have increased most in the period analysed.

In relation with the transport sector, there are various studies which identify its importance for Ecuador's emissions and propose improvements. In particular, Buenaño (2017) recognizes it as one of the most influential in Ecuador's generation of $\mathrm{CO}_{2}$ in 2013. In the same line, Guayanlema (2013) estimates that around 85 to $90 \%$ of emissions come from land transport (5-6\% from sea transport and an average of 3.8\% from air transport), and likewise indicates that extra petrol is the fuel most used for light transport, followed by diesel, for heavy load transport. One of the key elements to favour Ecuador's decarbonisation is the elimination or reduction of petrol and diesel subsidies with the aim of fostering other, alternative energy sources, though as Escribano (2019) and Schaffitzel et al. (2020) note, this is a very complex topic and one which is greatly rejected in Ecuadorian society. A proof of this is the derogation two weeks after its publication of the Executive Decree 883, which eliminated the subsidies of normal petrol and diesel.

Another action line, as Ramírez et al. (2018) point out, is electrification to mitigate these emissions. There are diverse programs promoted by the Ecuadorian government and aimed at the decarbonisation of transport. The Vehicle Renovation Plan - RENOVA - the National Plan for Bike Paths, and projects such as the Quito Metro and the Cuenca Tram (MAE 2017) stand out. In particular, the RENOVA Plan means to renovate the public transport car pool through the scrapping of units which have served their useful life, granting an economic incentive for purchasing new national production vehicles at a preferential price and via the waiving of customs tariffs for those that are imported (MTOP 2015). This plan was supplemented with new public transport renovation plans in Ecuador, such as the Plan Renova 2.0 (MTOP 2017). However, Guayanlema (2013) estimates that were the Plan RENOVA maintained until 2040, it would mean a reduction 
of not more than $3.11 \%$ of the emissions due to its being aimed uniquely at public transport, which only represents $5.43 \%$ of the total fuel consumption.

On the other hand, and as Jakob (2017) points out, as well as continuing with the initiatives of renovation of the vehicle pool (Quinde 2017), this should be supplemented with the promotion of electric vehicles and bike paths. There ought also to be an increase of public transport, the establishing of a carbon tax for public and private transport, and the promotion of environmental research and education.

Ecuador's government has as well adopted different initiatives with a view to reducing its emissions in the secondary sector, such as is the case of the project of Pollutant Release and Transfer Register (RETC) (MAE 2014b), with a validity period of 2010 to 2015, and whose aim has been to identify and account for pollutants, especially in the industrial sector. This project has continued in successive editions until now. Other initiatives have been the certification system - "Green Point" - for those producers which meet specific standards and carry out good environmental practices, and the creation in 2013 of the Ecuadorian Centre of Efficiency of Resources and Cleaner Production (CEER), in charge of diagnosing the production of firms (MAE 2017).

Additionally, other climate change mitigation measures adopted are mainly the Ministerial Agreement N² 264 of 2014 (MAE 2014a) and the Ministerial Agreement $N^{\circ}$ 140 of 2015 (MAE 2015). The former accords the Environmental Ecuadorian Recognition "Neutral Carbon", with the aim of reducing and offsetting GHG emissions by public and private natural and legal persons. The latter are integrated general environmental indicators, the calculation of the organisational ecological foot print, and economic incentives such as tax deductions and credits with environmental considerations are included.

\section{Conclusions.}

Ecuador's Carbon Footprint has had a massive growth of $145.26 \%$ between 2000 and 2015, showing an increase even greater than that of the emissions calculated according to the EPP (114.11\%), the country becoming a net importer of embodied emissions after having been a net exporter in 2000. Ecuador's growth of economic activity, its trade balance deficit (since 2008) and new consumption patterns explain this situation. 
The significant volume of domestic and imported emissions identify the secondary and transport sectors as keys to reduce Ecuador's emissions. The transition to an economy low in emissions shows the need to reduce the emissions embodied in the production not only of these sectors but of the rest of the sectors linked to them (indirect domestic emissions). Efforts must be especially concentrated on the primary sector and on Electricity, Gas and Water, as each of them constitutes 39\% of those domestic indirect emissions. These emissions for the electricity sector have almost tripled in the study period, albeit the growth has slowed down in the second sub-period, having gone from a variation rate of $129 \%$ between 2000 and 2008 to $25 \%$ between 2008 and 2015 . This supports the idea that the measures launched in the electricity sector in recent years are producing moderate results.

On the other hand, the importance of fostering a responsible and sustainable consumption compels reducing the emissions embodied in consumption; that is to say, the emissions identified in the CF. To do so, it is necessary to work on the domestic emissions, but this especially involves reducing the emissions embodied in the imports which have substantially increased in the period analysed. In this case, a significant increase of the emissions coming from the BRICS countries has been seen, as well as from the LAC region. In both cases the growths are greater in the first part of the period. This change has caused the deficit of the emissions balance and Ecuador's greater external dependence.

This calculation of the Ecuador's CF during the years 2000-2015 therefore strengthens the need to foster a change in the population's and the public administrations' consumption patterns. So it is recommended that the authorities, on the basis of these rigorously obtained results, allocate part of the public budget to measures oriented to sustainable consumption. These measures could be the extending of the RENOVA Plan to private vehicles and strong awareness campaigns about the degree of sustainability of imported products. This type of measures could slow down the strong growth of emissions per capita, indispensable to reduce the country's CF.

\section{Ethics approval and consent to participate.}

Not applicable 


\section{Consent for publication.}

Not applicable

Data availability.

The datasets used and/or analysed during the current study are available from the corresponding author on reasonable request.

\section{Competing interest.}

The authors declare that they have no competing interests.

\section{Funding.}

The authors received financial support from the Chair of Energy and Environmental Economics sponsored by Red Eléctrica España (REE) at the University of Seville. The first author received financial support from Universidad Autónoma de Chile (Chile). The first and second authors received financial support from the Spanish Ministerio de Ciencia, Innovación y Universidades, from the research project (RTI2018-096725-B-I00) and to the Fondo Europeo de Desarrollo Regional (FEDER) y a la Consejería de Economía, Conocimiento, Empresas y Universidad de la Junta de Andalucía (Programa Operativo FEDER 2014-2020) for the research project (US-1260925). None of the funding bodies have participated in the design of the study and collection, analysis or interpretation of data and in writing the manuscript.

\section{Authors' contributions}

RC (Román-Collado), SD (Sanz-Díaz) and L (Loja) contributed to the study conception, design, material preparation, data collection and analysis. RC was in charge of the supervision and funding acquisition.

\section{References}

Almazán-Gómez MA, Duarte R, Langarita R, Sánchez-Chóliz J (2019) Effects of water reallocation in the Ebro river basin: A multiregional input-output and geographical analysis. J. Environ. Manage. 241: 645-657. 
Banco

Mundial

(2020)

Datos:

País

Ecuador.

https://datos.bancomundial.org/pais/ecuador?view=chart (Accessed March 2020)

Blanchard JMF (2019) The Politics of Latin America's Investment and Other Links with China: Contextualizing the Region's Cash Chasing while Racking Richer Research Rewards. J. Chin. Polit. Sci. 24: 565-582

Bonilla D, Keller H, Schmiele J (2015) Climate policy and solutions for green supply chains: Europe's predicament. Supply Chain Manag. 20: 249-263

Buenaño B (2017) Actividad económica y emisiones de CO2: Ensayos empíricos para el Ecuador. Universidad Autónoma de Barcelona. https://ddd.uab.cat/record/187358 (Accessed 03 August 2018)

Carvajal PE, Li FG (2019) Challenges for hydropower-based nationally determined contributions: a case study for Ecuador. Clim. Policy. 19: 974-987

Carvajal PE, Li FG, Soria R, Cronin J, Anandarajah G, Mulugetta Y (2019) Large hydropower, decarbonisation and climate change uncertainty: Modelling power sector pathways for Ecuador. Energy Strateg. Rev. 23: 86-99

Casanova C, Xia L, Ferreira R (2016) Measuring Latin America's export dependency on China. Journal of Chinese Economic and Foreign Trade Studies 9: 213-233

Corporación Andina de Fomento (2014) Índice de vulnerabilidad y adaptación al cambio climático en la región de América Latina y el Caribe. Banco de Desarrollo de América Latina

David PN, Olga DML, Patricio AM (2015) The ecological footprint of nations. Overall thoughts and the Ecuadorian context. CIENCIA UNEMI, 8: 93-103

Davis S, Caldeira K (2010) Consumption-based accounting of CO2 emissions. Proceedings of the National Academy of Sciences. 107: 5687-5692

Deng G, Xu Y (2017) Accounting and structure decomposition analysis of embodied carbon trade: A global perspective. Energy, 137: 140-151 
Dolter B, Victor P (2016) Casting a long shadow: Demand-based accounting of Canada's greenhouse gas emissions responsibility. Ecol. Econ. 127: 156-164

Escribano G (2013) Ecuador's energy policy mix: Development versus conservation and nationalism with Chinese loans. Energy Policy. 57: 152-159

Escribano G (2019) Ecuador y los subsidios a los combustibles. Real Instituto Elcano.

Gao Z, Geng Y, Wu R, Zhang X, Pan H, Jiang H (2020) China's CO 2 emissions embodied in fixed capital formation and its spatial distribution. Environ Sci Pollut Res. 27:19970-19990.

Guayanlema V (2013) Inventario nacional de emisiones de gases de efecto invernadero en el sector transporte al 2012. Universidad Central del Ecuador. http://www.dspace.uce.edu.ec/bitstream/25000/1860/1/T-UCE-0017-43.pdf (Accessed March 2020)

Herrera-Vinelli L (2017) Latin America in Light of China's Global Economic Power: Brazil and Ecuador and their foreign policies. A Comparative Study. Temas de Nuestra América. Revista de Estudios Latinoamericanos. 33: 89-106

Hogenboom B (2014) Latin America and China's transnationalizing oil industry: A political economy assessment of new relations. Perspectives on Global Development and Technology. 13: 626-647

Jacobs D., Marzolf N, Paredes JR, Rickerson W, Flynn H, Becker-Birck C, Solano-Peralta M (2013) Analysis of renewable energy incentives in the Latin America and Caribbean region: The feed-in tariff case. Energy Policy. 60: 601-610

Jakob M (2017) Ecuador's climate targets: A credible entry point to a low-carbon economy? Energy Sustain Dev. 39: 91-100

Lapeña Sanz R, Czubala Ostapiuk MR (2018) The dependent foreign policy: the case of Ecuador. OASIS-Observatorio de Análisis de los Sistemas Internacionales. 28: $171-191$

Lenzen M, Kanemoto K, Moran D, Geschke A (2012) Mapping the Structure of the World Economy. Environmental Science and Technology. 46: 8374-8381 
Lenzen M, Moran D, Kanemoto K, Geschke A (2013) Building EORA: A Global MultiRegion Input-Output Database at High Country and Sector Resolution. Econ. Syst. Res. 25: 20-49

Leontief W (1936) Quantitative input and output relations in the economic system of the United States. Rev. Econ. Stat. 18: 105-125

Leontief W (1970) Environmental repercussions and the economic structure: an inputoutput approach. Rev. Econ. Stat. 52: 262-271

MAE (Ministerio del Ambiente de Ecuador) (2014a) Acuerdo Ministerial $N^{\circ}$ 264: Establecer el mecanismo para otorgar el reconocimiento Ecuatoriano Ambiental “Carbono Neutral". https://www.gob.ec/sites/default/files/regulations/201809/Documento 264 Mecanismo Otorgar Reconocimiento Carbono Neutral.pdf (Accessed June 2020)

MAE (Ministerio del Ambiente de Ecuador) (2014b) Proyecto RETC: Monitoreo, Reporte y Difusión de Contaminantes Orgánicos Persistentes COPs a través de un Registro de Emisiones y Transferencia de Contaminantes RETC en el Ecuador

MAE (Ministerio del Ambiente de Ecuador) (2015) Acuerdo Ministerial N 140: Expedir el marco institucional para incentivos ambientes. http://extwprlegs1.fao.org/docs/pdf/ecu155142.pdf (Accessed 28 August 2018)

MAE (Ministerio del Ambiente de Ecuador) (2017) Tercera Comunicación Nacional del Ecuador sobre Cambio Climático. http://www.ambiente.gob.ec/wpcontent/uploads/downloads/2017/10/TERCERA-COMUNICACION-BAJAseptiembre-20171-ilovepdf-compressed1.pdf ( Accessed 03 June 2018)

Margulis S (2016) Vulnerabilidad y adaptación de las ciudades de América Latina al cambio climático. Comisión Económica para América Latina y el Caribe. Santiago Martínez J, Martí-Herrero J, Villacís S, Riofrio AJ, Vaca D (2017) Analysis of energy, CO2 emissions and economy of the technological migration for clean cooking in Ecuador. Energy Policy. 107: 182-187 
MTOP (Ministerio de Transporte y Obras Públicas de Ecuador) (2015) Hasta el 2015 se amplía Plan de Renovación Vehicular-RENOVA. https://www.obraspublicas.gob.ec/hasta-el-2015-se-amplia-plan-derenovacion-vehicular-renova/ (Accessed 27 August 2018)

MTOP (Ministerio de Transporte y Obras Públicas de Ecuador) (2017) Firma de contratos de adhesión al Plan Renova 2.0. https://www.obraspublicas.gob.ec/firma-decontratos-de-adhesion-al-plan-renova-2-0/ (Accessed 27 August 2018)

Minx J, Wiedmann T, Wood R, Peters G, Lenzen M, Owen A, Scott K, Barrett J, Hubacek K, Baiocchi G, Paul A, Dawkins E, Briggs J, Guan D, Suh S, Ackerman F (2010) Input-Output Analysis and Carbon Footprinting: an overview of applications. Econ. Syst. Res. 21: 187-216

Muñoz P, Steininger K (2010) Austria's $\mathrm{CO}_{2}$ responsibility and the carbon content of its international trade. Ecol. Econ. 69: 2003-2019

Olivier J, Janssens-Maenhout G, Muntean M, Peters J (2016) Trends in global CO2 emissions: 2016 Report. European Commission, Joint Research Centre (EC-JRC), PBL Netherlands Environmental Assessment Agency. http://edgar.jrc.ec.europa.eu/news docs/jrc-2016-trends-in-global-co2emissions-2016-report-103425.pdf (Accessed 16 July 2018)

Peters G, Minx J, Weber C, Edenhofer O (2011) Growth in emission transfers via international trade from 1990 to 2008. Proceedings of the National Academy of Sciences. 10: 8903-8908

Quinde G (2017) Análisis de las emisiones de CO2 provocadas por el sector transporte en el Ecuador. Un análisis regional. http://dspace.utpl.edu.ec/bitstream/20.500.11962/21223/1/Quinde\%20Espa\% c3\%b1a\%20Gabriela\%20Karina.pdf (Accessed 27 August 2018)

Ramírez AD, Arcentales D, Boero A (2018) Mitigation of Greenhouse Gas Emissions Through the Shift From Fossil Fuels to Electricity in the Mass Transport System in Guayaquil, Ecuador. In ASME 2018 International Mechanical Engineering 
Congress and Exposition. American Society of Mechanical Engineers Digital Collection

Ramírez AD, Rivela B, Boero A, Melendres AM (2019) Lights and shadows of the environmental impacts of fossil-based electricity generation technologies: A contribution based on the Ecuadorian experience. Energy Policy. 125: 467-477

República de Ecuador (2008) Constitución de la República del Ecuador 2008. Decreto Legislativo 0 (cero) published in the Registro Oficial 449 of 20 October 2008

República de Ecuador (2017) Código Orgánico del Ambiente. Ley 0. Registro Oficial Suplemento 983 de 12 de abril de 2017.República de Ecuador. 2019. Primera contribución determinada a nivel nacional para el Acuerdo de París bajo la Convención Marco de Naciones Unidas sobre cambio climático

RIOCC (Red Iberoamericana de Oficinas de Cambio Climático). Cambio climático en Iberoamérica. Impactos y vulnerabilidad. Last Access: June 2020. http://www.lariocc.es/es/cambio-climatico-iberoamerica/impactos-vulnerabilidad/

Robalino-López A, Mena-Nieto A, García-Ramos JE (2014a) System dynamics modeling for renewable energy and CO2 emissions: A case study of Ecuador. Energy Sustain Dev. 20: 11-20

Robalino-López A, García-Ramos JE, Golpe AA, Mena-Nieto A (2014b) System dynamics modelling and the environmental Kuznets curve in Ecuador (1980-2025). Energy Policy. 67: 923-931

Robalino-López A, García-Ramos JE, Golpe AA, Mena-Nieto A (2016) CO2 emissions convergence among 10 South American countries. A study of Kaya components (1980-2010). Carbon Manag. 7: 1-12

Román R, Cansino JM, Rueda-Cantuche JM (2016) A multi-regional input-output analysis of ozone precursor emissions embodied in Spanish international trade. J. Clean Prod. 137: 1382-1392

Román-Collado R, Morales-Carrión AV (2018) Towards a sustainable growth in Latin America: A multiregional spatial decomposition analysis of the driving forces behind CO2 emissions changes. Energy Policy. 115: 273-280 
Samanamud GT (2014) China en América Latina: los casos de Ecuador y Perú entre los años 2009-2012, ¿es posible una apuesta hacia el futuro? Anuario Mexicano de Derecho Internacional. 14: 221-260.

Schaffitzel F, Jakob M, Soria R, Vogt-Schilb A, Ward H (2020) Can government transfers make energy subsidy reform socially acceptable? A case study on Ecuador. Energy Policy. 137: 111-120

Secretaría Nacional de Planificación y Desarrollo (SENPLADES) (2009) Plan Nacional para el Buen Vivir 2009-2013. http://www.planificacion.gob.ec/wpcontent/uploads/downloads/2012/07/Plan Nacional para el Buen Vivir.pdf (Accessed 17 May 2018)

Secretaría Nacional de Planificación y Desarrollo (SENPLADES) (2013) Plan Nacional para el Buen Vivir 2013-2017. http://www.buenvivir.gob.ec/ (Accessed 17 May 2018).

Secretaría Nacional de Planificación y Desarrollo (2018) Plan Nacional de Desarrollo, 2017-2021. Toda una vida. Resolución no 003-2017-CNP. Boletín 234

Steen-Olsen K, Owen A, Hertwich E, Lenzen M (2014) Effects of Sector Aggregation on CO2 Multipliers in Multiregional Input-output Analyses. Econ. Syst. Res. 26: 284302

Steen-Olsen K, Owen A, Barrett J, Guan D, Hertwich E, Lenzen M, Wiedmann T (2016) Accounting for value added embodied in trade and consumption: an intercomparison of global multiregional input-output databases. Econ. Syst. Res. 28: $78-94$

Tapia-Armijos MF, Homeier J, Munt DD (2017) Spatio-temporal analysis of the human footprint in South Ecuador: Influence of human pressure on ecosystems and effectiveness of protected areas. Appl. Geogr. 78: 22-32

Torres JF (2019) Cambio climático y populismos en América Latina: Un análisis comparativo de los posicionamientos de Argentina, Ecuador, Chile y Brasil en el camino al acuerdo de París de 2015. Prometeica-Revista de Filosofía y Ciencias. 18: $24-35$ 
Toulkeridis T, Tamayo E, Simón-Baile D, Merizalde-Mora MJ, Reyes-Yunga DF, VieraTorres M, Heredia M (2020) Climate Change according to Ecuadorian academicsPerceptions versus facts. La Granja, 31: 21-46

Tukker A, Bulavskaya T, Giljum S, de Koning A, Lutter S, Simas M, Stadler K, Wood R (2016) Environmental and resource footprints in a global context: Europe's structural deficit in resource endowments. Global Environ. Change. 40, 171-181

Turner K, McGregor P, Swales J (2008) The $\mathrm{CO}_{2}$ 'trade balance' between Scotland and the rest of the UK: Performing a multi-region environmental input-output analysis with limited data. Ecol. Econ. 66: 662-673

Wilting C, Vringer K (2010) Carbon and land use accounting from a producer's and a consumer's perspective - an empirical examination covering the world. Econ. Syst. Res. 21: 291-310

Zhang Y, Chen Y, Huang M (2019) Water Footprint and Virtual Water Accounting for China Using a Multi-Regional Input-Output Model. Water. 11: 34

1. Rony Parra, Louisa Jane Di Felice, Mario Giampietro, Jesus Ramos-Martin, 2018. The metabolism of oil extraction: A bottom-up approach applied to the case of $\begin{array}{lllll}\text { Ecuador. } & \text { Energy } & \text { Policy } & \text { 63-74 }\end{array}$ 2. Rony Parra, Sandra G.F. Bukkens, Mario Giampietro, 2020. Exploration of the environmental implications of ageing conventional oil reserves with relational analysis. Science of the Total Environment 749, 142371 


\section{ANNEX A}

Table A1: Original classification of sectors contained in Eora26 and aggregation for the analysis of the study.

\begin{tabular}{|c|c|c|c|}
\hline \multicolumn{2}{|r|}{ Sectoral Classification in Eora26: } & \multicolumn{2}{|c|}{ Aggregation } \\
\hline 1 & Agriculture & \multirow{3}{*}{1} & \multirow{3}{*}{ Primary Sector } \\
\hline 2 & Fishing & & \\
\hline 3 & Mines and quarries & & \\
\hline 4 & Food and beverages & \multirow{9}{*}{2} & \multirow{9}{*}{ Secondary Sector } \\
\hline 5 & Textiles and clothing & & \\
\hline 6 & Wood and paper & & \\
\hline 7 & $\begin{array}{l}\text { Petroleum, chemical and non-metallic mineral } \\
\text { products }\end{array}$ & & \\
\hline 8 & Metallic products & & \\
\hline 9 & Electrical and machinery & & \\
\hline 10 & Transport Equipment & & \\
\hline 11 & Other industrial sectors & & \\
\hline 12 & Recycling & & \\
\hline 13 & Electricity, gas and water & 3 & Electricity, Gas and Water \\
\hline 14 & Construction & 4 & Construction \\
\hline 15 & Maintenance and repair & \multirow{4}{*}{5} & \multirow{4}{*}{ Hotels and trade } \\
\hline 16 & Wholesale trade & & \\
\hline 17 & Retail trade & & \\
\hline 18 & Hotels and restaurants & & \\
\hline 19 & Transport & 6 & Transport \\
\hline 20 & Post and telecommunications & \multirow{6}{*}{7} & \multirow{6}{*}{ Other Services } \\
\hline 21 & \begin{tabular}{|lll}
$\begin{array}{l}\text { Financial intermediation and commercial } \\
\text { activities }\end{array}$ & \\
\end{tabular} & & \\
\hline 22 & Public administration & & \\
\hline 23 & Education, health and other services & & \\
\hline 24 & Private homes & & \\
\hline 25 & Others & & \\
\hline 26 & Re-exports and re-imports & 8 & $\begin{array}{l}\text { Re-exports and re- } \\
\text { imports }\end{array}$ \\
\hline
\end{tabular}


Table A2: Original classification of Eora26 countries by analysis regions.

Region: BRICS

\begin{tabular}{|c|c|c|c|c|c|}
\hline \multicolumn{2}{|c|}{ Region: BRICS } & \multicolumn{2}{|c|}{ Region: North America (NA) } & \multicolumn{2}{|c|}{ Region: Ecuador (ECU) } \\
\hline $\begin{array}{c}\text { Eora26 } \\
\text { Numbering }\end{array}$ & Country & $\begin{array}{c}\text { Eora26 } \\
\text { Numbering }\end{array}$ & Country & $\begin{array}{c}\text { Eora26 } \\
\text { Numbering }\end{array}$ & Country \\
\hline 26 & Brazil & 34 & Canada & 54 & Ecuador \\
\hline 40 & China & 70 & Greenland & & \\
\hline 79 & India & 181 & USA & & \\
\hline 142 & Russia & & & & \\
\hline 156 & South Africa & & & & \\
\hline
\end{tabular}

Region: European Union (EUE)

\begin{tabular}{|c|c|c|c|c|c|}
\hline $\begin{array}{c}\text { Eora26 } \\
\text { Numbering }\end{array}$ & Country & $\begin{array}{c}\text { Eora26 } \\
\text { Numbering }\end{array}$ & Country & $\begin{array}{c}\text { Eora26 } \\
\text { Numbering }\end{array}$ & Country \\
\hline $\mathbf{1 1}$ & Austria & $\mathbf{6 9}$ & Greece & $\mathbf{1 3 6}$ & Poland \\
\hline $\mathbf{1 8}$ & Belgium & $\mathbf{7 7}$ & Hungary & $\mathbf{1 3 7}$ & Portugal \\
\hline $\mathbf{2 9}$ & Bulgaria & $\mathbf{8 3}$ & Ireland & $\mathbf{1 4 1}$ & Romania \\
\hline $\mathbf{4 6}$ & Cyprus & $\mathbf{8 5}$ & Italy & $\mathbf{1 5 3}$ & Slovakia \\
\hline $\mathbf{4 7}$ & Czech Republic & $\mathbf{9 4}$ & Latvia & $\mathbf{1 5 4}$ & Slovenia \\
\hline $\mathbf{5 1}$ & Denmark & $\mathbf{1 0 0}$ & Lithuania & $\mathbf{1 5 8}$ & Spain \\
\hline $\mathbf{5 8}$ & Estonia & $\mathbf{1 0 1}$ & Luxembourg & $\mathbf{1 6 3}$ & Sweden \\
\hline $\mathbf{6 1}$ & Finland & $\mathbf{1 0 8}$ & Malta & $\mathbf{1 7 9}$ & UK \\
\hline $\mathbf{6 2}$ & France & $\mathbf{1 2 0}$ & Netherlands & & \\
\cline { 1 - 3 } & Germany & $\mathbf{1 2 7}$ & Norway & &
\end{tabular}

Región: América Latina y el Caribe (ACL)

\begin{tabular}{|c|c|c|c|c|c|}
\hline $\begin{array}{c}\text { Eora26 } \\
\text { Numbering }\end{array}$ & Country & $\begin{array}{c}\text { Eora26 } \\
\text { Numbering }\end{array}$ & Country & $\begin{array}{c}\text { Eora26 } \\
\text { Numbering }\end{array}$ & Country \\
\hline 6 & Antigua & 41 & Colombia & 111 & Mexico \\
\hline 7 & Argentina & 43 & Costa Rica & 124 & Nicaragua \\
\hline 9 & Aruba & 45 & Cuba & 131 & Panama \\
\hline 13 & Bahamas & 53 & $\begin{array}{c}\text { Dominican } \\
\text { Republic }\end{array}$ & 133 & Paraguay \\
\hline 16 & Barbados & 56 & El Salvador & 134 & Peru \\
\hline 19 & Belize & 71 & Guatemala & 146 & $\begin{array}{c}\text { Sao Tome and } \\
\text { Principe }\end{array}$ \\
\hline 21 & Bermuda & 73 & Guyana & 171 & $\begin{array}{c}\text { Trinidad and } \\
\text { Tobago }\end{array}$ \\
\hline 23 & Bolivia & 74 & Haiti & 182 & Uruguay \\
\hline 27 & $\begin{array}{l}\text { British Virgin } \\
\text { Islands }\end{array}$ & 75 & Honduras & 185 & Venezuela \\
\hline 39 & Chile & 86 & Jamaica & & \\
\hline
\end{tabular}




\begin{tabular}{|c|c|c|c|c|c|}
\hline \multicolumn{6}{|c|}{ Region: Rest of the World (RoW) } \\
\hline $\begin{array}{c}\text { Eora26 } \\
\text { Numbering }\end{array}$ & Country & $\begin{array}{c}\text { Eora26 } \\
\text { Numbering }\end{array}$ & Country & $\begin{array}{c}\text { Eora26 } \\
\text { Numbering }\end{array}$ & Country \\
\hline 1 & Afghanistan & 78 & Iceland & 132 & $\begin{array}{c}\text { Papua New } \\
\text { Guinea }\end{array}$ \\
\hline 2 & Albania & 80 & Indonesia & 135 & Philippines \\
\hline 3 & Algeria & 81 & Iran & 138 & Qatar \\
\hline 4 & Andorra & 82 & Iraq & 139 & South Korea \\
\hline 5 & Angola & 84 & Israel & 140 & Moldova \\
\hline 8 & Armenia & 87 & Japan & 143 & Rwanda \\
\hline 10 & Australia & 88 & Jordan & 144 & Samoa \\
\hline 12 & Azerbaijan & 89 & Kazakhstan & 145 & San Marino \\
\hline 14 & Bahrain & 90 & Kenya & 147 & Saudi Arabia \\
\hline 15 & Bangladesh & 91 & Kuwait & 148 & Senegal \\
\hline 17 & Belarus & 92 & Kyrgyzstan & 149 & Serbia \\
\hline 20 & Benin & 93 & Laos & 150 & Seychelles \\
\hline 22 & Bhutan & 95 & Lebanon & 151 & Sierra Leone \\
\hline 24 & $\begin{array}{l}\text { Bosnia and } \\
\text { Herzegovina }\end{array}$ & 96 & Lesotho & 152 & Singapore \\
\hline 25 & Botswana & 97 & Liberia & 155 & Somalia \\
\hline 28 & Brunei & 98 & Libya & 157 & South Sudan \\
\hline 30 & Burkina Faso & 99 & Liechtenstein & 159 & Sri Lanka \\
\hline 31 & Burundi & 102 & Macao SAR & 160 & Sudan \\
\hline 32 & Cambodia & 103 & Madagascar & 161 & Suriname \\
\hline 33 & Cameroon & 104 & Malawi & 162 & Swaziland \\
\hline 35 & Cape Verde & 105 & Malaysia & 164 & Switzerland \\
\hline 36 & Cayman Islands & 106 & Maldives & 165 & Syria \\
\hline 37 & $\begin{array}{l}\text { Central African } \\
\text { Republic }\end{array}$ & 107 & Mali & 166 & Taiwan \\
\hline 38 & Chad & 109 & Mauritania & 167 & Tajikistan \\
\hline 42 & Congo & 110 & Mauritius & 168 & Thailand \\
\hline 44 & Croatia & 112 & Monaco & 169 & $\begin{array}{c}\text { TFYR } \\
\text { Macedonia }\end{array}$ \\
\hline 48 & Cote d'Ivoire & 113 & Mongolia & 170 & Togo \\
\hline 49 & North Korea & 114 & Montenegro & 172 & Tunisia \\
\hline 50 & DR Congo & 115 & Morocco & 173 & Turkey \\
\hline 52 & Djibouti & 116 & Mozambique & 174 & Turkmenistan \\
\hline 55 & Egypt & 117 & Myanmar & 175 & Former USSR \\
\hline 57 & Eritrea & 118 & Namibia & 176 & Uganda \\
\hline 59 & Ethiopia & 119 & Nepal & 177 & Ukraine \\
\hline 60 & $\mathrm{Fiji}$ & 121 & $\begin{array}{l}\text { Netherland } \\
\text { Antilles }\end{array}$ & 178 & UAE \\
\hline 63 & French Polynesia & 122 & New Caledonia & 180 & Tanzania \\
\hline 64 & Gabon & 123 & New Zealand & 183 & Uzbekistan \\
\hline 65 & Gambia & 125 & Niger & 184 & Vanuatu \\
\hline 66 & Georgia & 126 & Nigeria & 186 & Vietnam \\
\hline 68 & Ghana & 128 & Gaza Strip & 187 & Yemen \\
\hline 72 & Guinea & 129 & Oman & 188 & Zambia \\
\hline 76 & Hong Kong & 130 & Pakistan & 189 & Zimbabwe \\
\hline
\end{tabular}




\section{ANNEX B}

Table B1: Volume of $\mathrm{CO}_{2}$ emissions, by regions and years (Gigagrams)

\begin{tabular}{|c|c|c|c|c|c|c|c|c|}
\hline & & ECU & LAC & NA & EU & BRICS & RoW & EPP \\
\hline \multirow{3}{*}{ ECU } & 2000 & 14039.93 & 1629.07 & 1676.28 & 826.66 & 291.21 & 1035.80 & 19498.95 \\
\hline & 2008 & 22721.32 & 2563.25 & 2293.92 & 1303.64 & 622.98 & 1377.76 & 30882.86 \\
\hline & 2015 & 33322.58 & 3146.58 & 2021.90 & 1098.19 & 727.12 & 1432.72 & 41749.09 \\
\hline \multirow{3}{*}{ LAC } & 2000 & 1126.29 & 777170.22 & 119002.88 & 21951.04 & 13286.52 & 16552.68 & 949089.63 \\
\hline & 2008 & 2414.86 & 919661.61 & 146601.10 & 34495.77 & 35565.54 & 25597.30 & 1164336.18 \\
\hline & 2015 & 3356.06 & 1029958.92 & 132965.62 & 27658.54 & 39290.15 & 25174.67 & 1258403.97 \\
\hline \multirow{3}{*}{ NA } & 2000 & 1407.59 & 113017.63 & 5843364.24 & 181087.11 & 51096.17 & 235314.38 & 6425287.12 \\
\hline & 2008 & 2401.97 & 133876.58 & 5520792.89 & 211830.15 & 93617.77 & 260720.01 & 6223239.37 \\
\hline & 2015 & 3145.64 & 139344.14 & 5033514.99 & 172683.93 & 121978.80 & 257030.53 & 5727698.02 \\
\hline \multirow{3}{*}{ EU } & 2000 & 528.97 & 34862.58 & 223401.38 & 3546746.20 & 68797.49 & 243777.60 & 4118114.23 \\
\hline & 2008 & 899.33 & 40949.88 & 207320.86 & 3430125.82 & 139042.90 & 311016.50 & 4129355.29 \\
\hline & 2015 & 1083.43 & 41062.18 & 159701.07 & 2825348.49 & 165932.62 & 299113.09 & 3492240.87 \\
\hline \multirow{3}{*}{ BRICS } & 2000 & 700.39 & 61785.18 & 490412.32 & 626972.69 & 5167020.85 & 680015.63 & 7026907.07 \\
\hline & 2008 & 2159.47 & 119537.55 & 835746.28 & 982687.40 & 8626032.26 & 1266521.53 & 11832684.49 \\
\hline & 2015 & 2975.79 & 142309.56 & 759025.28 & 874402.42 & 12582580.42 & 1399722.77 & 15761016.24 \\
\hline \multirow{3}{*}{ RoW } & 2000 & 750.86 & 46651.61 & 465000.88 & 531406.62 & 256386.49 & 4830628.43 & 6130824.90 \\
\hline & 2008 & 1217.28 & 58683.67 & 478308.91 & 611477.78 & 515146.94 & 5960574.31 & 7625408.90 \\
\hline & 2015 & 1622.52 & 66299.49 & 420900.89 & 537264.40 & 668317.12 & 6910084.30 & 8604488.71 \\
\hline \multirow{3}{*}{$\begin{array}{l}\text { Carbon } \\
\text { footprint }\end{array}$} & 2000 & 18554.02 & 1035116.30 & 7142857.99 & 4908990.34 & 5556878.72 & 6007324.52 & 24669721.89 \\
\hline & 2008 & 31814.24 & 1275272.53 & 7191063.96 & 5271920.56 & 9410028.39 & 7825807.40 & 31005907.08 \\
\hline & 2015 & 45506.01 & 1422120.87 & 6508129.75 & 4438455.97 & 13578826.23 & 8892558.08 & 34885596.90 \\
\hline \multirow{3}{*}{ Import. } & 2000 & 4514.09 & 257946.08 & 1299493.75 & 1362244.13 & 389857.87 & 1176696.09 & \\
\hline & 2008 & 9092.92 & 355610.93 & 1670271.07 & 1841794.74 & 783996.13 & 1865233.09 & \\
\hline & 2015 & 12183.43 & 392161.94 & 1474614.75 & 1613107.49 & 996245.80 & 1982473.78 & \\
\hline \multirow{3}{*}{ Export. } & 2000 & 5459.02 & 171919.41 & 581922.88 & 571368.02 & 1859886.22 & 1300196.47 & \\
\hline & 2008 & 8161.54 & 244674.57 & 702446.48 & 699229.46 & 3206652.23 & 1664834.59 & \\
\hline & 2015 & 8426.51 & 228445.04 & 694183.03 & 666892.38 & 3178435.82 & 1694404.41 & \\
\hline \multirow{3}{*}{ EEIT } & 2000 & 9973.11 & 429865.49 & 1881416.62 & 1933612.15 & 2249744.09 & 2476892.56 & \\
\hline & 2008 & 17254.46 & 600285.50 & 2372717.55 & 2541024.20 & 3990648.36 & 3530067.68 & \\
\hline & 2015 & 20609.93 & 620606.98 & 2168797.79 & 2279999.87 & 4174681.62 & 3676878.20 & \\
\hline \multirow{3}{*}{ ETB } & 2000 & 944.93 & -86026.67 & -717570.87 & -790876.11 & 1470028.35 & 123500.38 & \\
\hline & 2008 & -931.37 & -110936.35 & -967824.59 & -1142565.28 & 2422656.09 & -200398.50 & \\
\hline & 2015 & -3756.92 & -163716.90 & -780431.72 & -946215.10 & 2182190.01 & -288069.37 & \\
\hline
\end{tabular}

Source: Own elaboration

Note: The data in the Diagonal correspond to the Self-consumption of domestic trade, the data on the horizontal level concern exports to the distinct regions, and the data on the vertical level are the imports of the country from the distinct origin regions. 
Table B2. Breakdown of the CF

\begin{tabular}{|c|c|c|c|c|c|}
\hline & & Direct CF & $\begin{array}{c}\text { Domestic } \\
\text { indirect CF }\end{array}$ & $\begin{array}{c}\text { Import } \\
\text { indirect CF }\end{array}$ & $\mathrm{CF}$ \\
\hline \multirow{3}{*}{ Primary Sector } & 2000 & 170.96 & 360.26 & 183.50 & 714.72 \\
\hline & 2008 & 323.74 & 431.90 & 335.16 & 1090.80 \\
\hline & 2015 & 640.37 & 533.60 & 426.70 & 1600.68 \\
\hline \multirow{3}{*}{$\begin{array}{l}\text { Secondary } \\
\text { Sector }\end{array}$} & 2000 & 1962.03 & 1836.85 & 2146.65 & 5945.54 \\
\hline & 2008 & 2809.47 & 3028.56 & 4114.99 & 9953.02 \\
\hline & 2015 & 4564.71 & 4098.34 & 5589.40 & 14252.44 \\
\hline \multirow{3}{*}{$\begin{array}{c}\text { Electricity, Gas } \\
\text { and Water }\end{array}$} & 2000 & 968.08 & 105.56 & 40.87 & 1114.51 \\
\hline & 2008 & 1953.65 & 150.16 & 70.12 & 2173.93 \\
\hline & 2015 & 2905.41 & 215.47 & 94.58 & 3215.46 \\
\hline \multirow{3}{*}{ Construction } & 2000 & 328.16 & 947.21 & 367.35 & 1642.73 \\
\hline & 2008 & 508.85 & 1452.26 & 781.24 & 2742.35 \\
\hline & 2015 & 715.40 & 1973.02 & 932.00 & 3620.43 \\
\hline \multirow{3}{*}{$\begin{array}{l}\text { Hotels and } \\
\text { Trade }\end{array}$} & 2000 & 27.77 & 183.18 & 49.15 & 260.10 \\
\hline & 2008 & 59.32 & 322.72 & 96.04 & 478.09 \\
\hline & 2015 & 121.37 & 423.62 & 106.50 & 651.50 \\
\hline \multirow{3}{*}{ Transport } & 2000 & 5645.71 & 672.99 & 1418.28 & 7736.99 \\
\hline & 2008 & 8560.75 & 925.87 & 3000.10 & 12486.72 \\
\hline & 2015 & 12611.36 & 1310.56 & 4218.77 & 18140.68 \\
\hline \multirow{3}{*}{ Other Services } & 2000 & 114.21 & 716.86 & 270.60 & 1101.68 \\
\hline & 2008 & 420.07 & 1773.81 & 624.07 & 2817.96 \\
\hline & 2015 & 962.94 & 2246.13 & 710.93 & 3920.01 \\
\hline \multirow{3}{*}{$\begin{array}{c}\text { Re-export \& re- } \\
\text { import }\end{array}$} & 2000 & 0.00 & 0.07 & 37.68 & 37.75 \\
\hline & 2008 & 0.00 & 0.18 & 71.19 & 71.37 \\
\hline & 2015 & 0.00 & 0.28 & 104.54 & 104.82 \\
\hline
\end{tabular}


Table B3. Import indirect CF

\begin{tabular}{|c|c|c|c|c|c|c|c|}
\hline \multirow{4}{*}{$\begin{array}{l}\text { Primary } \\
\text { Sector }\end{array}$} & & LAC & NA & EU & BRICS & RoW & TOTAL \\
\hline & 2000 & 46.94 & 56.87 & 22.95 & 23.13 & 33.61 & 183.50 \\
\hline & 2008 & 94.83 & 95.01 & 35.57 & 60.14 & 49.62 & 335.16 \\
\hline & 2015 & 124.75 & 117.20 & 39.33 & 79.34 & 66.09 & 426.70 \\
\hline \multirow{3}{*}{$\begin{array}{l}\text { Secondary } \\
\text { Sector }\end{array}$} & 2000 & 526.33 & 559.57 & 293.73 & 411.64 & 355.38 & 2146.65 \\
\hline & 2008 & 1016.30 & 749.54 & 475.88 & 1291.06 & 582.21 & 4114.99 \\
\hline & 2015 & 1424.95 & 952.04 & 586.11 & 1830.14 & 796.16 & 5589.40 \\
\hline \multirow{3}{*}{$\begin{array}{c}\text { Electricity, } \\
\text { Gas and } \\
\text { Water }\end{array}$} & 2000 & 9.05 & 9.34 & 4.53 & 6.35 & 11.60 & 40.87 \\
\hline & 2008 & 17.22 & 15.81 & 6.92 & 17.41 & 12.76 & 70.12 \\
\hline & 2015 & 21.98 & 18.19 & 7.52 & 22.66 & 24.23 & 94.58 \\
\hline \multirow{3}{*}{ Construction } & 2000 & 98.12 & 84.34 & 50.66 & 73.59 & 60.64 & 367.35 \\
\hline & 2008 & 219.86 & 129.24 & 88.29 & 238.37 & 105.48 & 781.24 \\
\hline & 2015 & 271.14 & 145.93 & 90.86 & 304.21 & 119.86 & 932.00 \\
\hline \multirow{3}{*}{$\begin{array}{l}\text { Hotels and } \\
\text { Trade }\end{array}$} & 2000 & 12.41 & 13.01 & 6.43 & 6.99 & 10.31 & 49.15 \\
\hline & 2008 & 25.40 & 21.57 & 10.77 & 21.23 & 17.07 & 96.04 \\
\hline & 2015 & 28.23 & 22.39 & 10.22 & 24.90 & 20.77 & 106.50 \\
\hline \multirow{3}{*}{ Transport } & 2000 & 369.63 & 611.83 & 107.52 & 117.54 & 211.76 & 1418.28 \\
\hline & 2008 & 890.46 & 1248.13 & 201.71 & 333.30 & 326.49 & 3000.10 \\
\hline & 2015 & 1309.45 & 1729.86 & 264.40 & 475.33 & 439.74 & 4218.77 \\
\hline \multirow{3}{*}{$\begin{array}{c}\text { Other } \\
\text { Services }\end{array}$} & 2000 & 62.84 & 68.45 & 30.18 & 50.50 & 58.63 & 270.60 \\
\hline & 2008 & 147.52 & 135.17 & 59.20 & 173.81 & 108.37 & 624.07 \\
\hline & 2015 & 171.10 & 149.53 & 57.53 & 201.46 & 131.31 & 710.93 \\
\hline \multirow{3}{*}{$\begin{array}{c}\text { Re-export \& } \\
\text { re-import }\end{array}$} & 2000 & 0.96 & 4.18 & 12.97 & 10.63 & 8.94 & 37.68 \\
\hline & 2008 & 3.25 & 7.51 & 20.99 & 24.15 & 15.29 & 71.19 \\
\hline & 2015 & 4.46 & 10.51 & 27.47 & 37.75 & 24.36 & 104.54 \\
\hline
\end{tabular}

